\title{
DOPUŠTENE I ZABRANJENE UGOVORNE ODREDBE KOD UGOVORA O FRANŠIZINGU U KONTEKSTU EUROPSKOGA PRAVA TRŽIŠNOG NATJECANJA ${ }^{1}$
}

Lidija Šimunović, mag. iur.

Pravni fakultet Sveučilišta u Osijeku
UDK: $347.71: 339.13 .053 .1$

Ur.: 5. travnja 2016.

Pr.: 11. srpnja 2016.

Pregledni znanstveni rad

\section{Sažetak}

Odnos između davatelja i primatelja franšize kod ugovora o franšizingu otvara niz pravnih pitanja u europskome pravu tržišnog natjecanja koja do sada nisu obrađivana u domaćoj pravnoj literaturi. Sjedne strane, EU kod ovog ugovora dopušta nametanje velikoga broja restriktivnih ugovornih odredbi koje bi inače po redovitom tijeku stvari bile zabranjene. S druge strane, u praksi je uočeno da se spomenuta (restriktivna) ograničenja ponekad koriste kao legitimno sredstvo za ograničavanje tržišnog natjecanja i slabljenje položaja primatelja franšize. Cilj je rada kroz kritičku analizu relevantne pravne stečevine EU-a dati prikaz dopuštenih $i$ zabranjenih ugovornih odredbi kod ugovora o franšizingu $u$ kontekstu europskoga prava tržišnog natjecanja i time odgovoriti na pitanja kada i pod kojim uvjetima navedena zaštita postaje platforma za legitimnu zloupotrebu.

U prvom dijelu definiraju se pojmovi i pravna stečevina EU-a koji se odnose na predmetnu materiju. Potom se analiziraju dopuštene i zabranjene ugovorne odredbe između primatelja $i$ davatelja franšize kod ugovora o franšizingu u kontekstu europskoga prava tržišnog natjecanja. Na kraju se iznosi načelna ocjena stanja i daju smjernice za buduća kretanja normativne aktivnosti EU-a $i$ poslovne prakse u pogledu ove materije u kontekstu europskoga prava tržišnog natjecanja.

Ključne riječi: pravo tržišnoga natjecanja, vertikalni sporazumi, ugovor o franšizingu, vertikalna ograničenja, ugovorne odredbe.

1 Rad je nastao kao rezultat jednomjesečnoga istraživanja provedenoga na Sveučilištu u Beču u sklopu stipendije One-Month Research Grant at the University of Vienna koju je financiralo Sveučilište u Beču. Akademski mentori pri odabiru teme i tijekom istraživanja bili su: prof. dr. sc. Christian Zib (Pravni fakultet Sveučilišta u Beču), dr. sc. Roman Router (Pravni fakultet Sveučilišta u Beču) i prof. dr. sc. Petar Miladin (Pravni fakultet Sveučilišta u Zagrebu). 


\section{1. $U$ VOD}

Ugovor o franšizingu oblikovan je u američkoj poslovnoj i sudskoj praksi na prijelazu iz 19. u 20. stoljeće. Na području Europe pojavio se tek šezdesetih godina 20. stoljeća dolaskom poznatih američkih davatelja franšize na europsko tržište (Coca Cola, McDonald's i dr.) $)^{2}$. Od ukupno dvadeset osam država članica EU-a, danas samo osam njih izrijekom regulira ugovor o franšizingu u svojim nacionalnim propisima, dok je kod ostalih riječ o autonomnom trgovačkom ugovoru koji je stvorila trgovačka praksa $^{3}$. Stoga je EU pridonio mjestimičnoj unifikaciji i/ili harmonizaciji dopuštenih i zabranjenih ugovornih odredbi kod ugovora o franšizingu u kontekstu europskoga prava tržišnog natjecanja. To je posredno promijenilo poslovnu praksu i omogućilo promatranje predmetne materije iz perspektive očuvanja i unaprjeđenja zajedničkog tržišta EU-a.

Unatoč tomu napori EU-a stvorili su određene pravne nejasnoće. S jedne strane, EU u odnosu između davatelja i primatelja franšize dopušta ugovaranje zaštitnih ugovornih odredbi koje bi inače po redovitom tijeku stvari bile zabranjene sa stajališta europskoga prava tržišnoga natjecanja. S druge strane, takva zaštita može biti pravna osnova kojom davatelj franšize nameće pretjerane obveze primatelju franšize. Stoga se nameću sljedeća pitanja. Koja je gornja granica dopustivosti takvih restriktivnih ugovornih odredbi? Jesu li zaštita prava davatelja franšize te očuvanje identiteta i ugleda franšizne mreže uvijek dovoljan argument za nametanje takvih odredbi?

Cilj je ovoga rada otkloniti spomenute nejasnoće i doprinijeti ujednačenosti u tumačenju pravne stečevine EU-a koje se tiču predmetne problematike. U radu se najprije definiraju ključni pojmovi i relevantna pravna stečevina EU-a za razradu teme. Središnji dio rada posvećen je sustavnoj analizi dopuštenih i zabranjenih ugovornih odredbi između primatelja i davatelja franšize, pri čemu se iznose stavovi i kritička zapažanja u kontekstu europskoga prava tržišnog natjecanja koja su do sada izostala u hrvatskoj pravnoj literaturi. Zaključno, iznosi se načelna ocjena stava EU-a prema ugovoru o franšizingu i daju smjernice za buduća kretanja pravne regulative EU-a i poslovne prakse.

\section{POJMOVNO ODREĐENJE}

Ugovor o franšizingu obično se definira kao pravni odnos između davatelja i primatelja franšize stvoren radi distribucije robe i usluga kroz franšiznu mrežu pravno i materijalno nezavisnih poduzetnika koji ne djeluju na istoj razini tržišta, na način da ta mreža prema trećima ostavlja dojam kao da je riječ o jednom poduzetniku. ${ }^{4}$

2 Mlikotin-Tomić, D., Ugovor o franchisingu, Informator, Zagreb, 1986., str. 10. i 12.

3 Tih osam država su: Francuska, Španjolska, Rumunjska, Italija Litva, Estonija, Švedska, Belgija. O tomu detaljnije u: Abell, M., The Regulation of Franchising in EU Member State, International Journal of Franchising Law, Clarehout, London, 2012., vol. 10., br. 2., str. 17.

4 S obzirom na različite prilike na američkom i europskom tržištu, ugovor o franšizingu, po svom se pravnom poimanju razlikuje u EU i SAD-u. U EU predstavlja samo jednu od više vrsta distribucije dobara i usluga. Stoga u kontekstu europskoga prava tržišnog natjecanja razlikujemo sedam metoda distribucije proizvoda i usluga: 1 . distribucija putem podružnice, 
EU takve sporazume naziva vertikalnim sporazumima jer ih u pravilu sklapaju poduzetnici koji nisu natjecatelji na tržištu (npr. distributer i prodavatelj robe). ${ }^{5} \mathrm{Za}$ razliku od horizontalnih sporazuma (npr. distributer i distributer), gdje se povezuju poduzetnici koji su međusobni natjecatelji na tržištu, ovdje je riječ o povezivanju poduzetnika koji djeluju na različitim razinama proizvodnog, odnosno distributivnog lanca. ${ }^{6}$

Primjerice davatelj franšize vlasnik je franšizne mreže kozmetičkih salona u kojima se rade jedinstveni tretmani ljepote upotrebom uređaja koje je on osmislio. U tom slučaju on djeluje na tržištu proizvođača uređaja za uljepšavanje i ujedno daje franšizu za otvaranje kozmetičkih salona. Svaki primatelj franšize kojega primi u svoju franšiznu mrežu mora koristiti njegove uređaje na propisan način te mora usvojiti jedinstven način rada, opremu i izgled kozmetičkih salona. Ulaskom u franšiznu mrežu primatelja franšize djeluje na tržištu pružatelja kozmetičkih usluga. Tu je u odnosu između davatelja i primatelja franšize riječ o vertikalnim odnosima, a u odnosu između primatelja franšize koji su članovi iste franšizne mreže, riječ je o horizontalnim odnosima. ${ }^{7}$

Iako naizgled dopušten, suradnički odnos između davatelja i primatelja franšize također može ograničiti tržišno natjecanje ako predmetni ugovor o franšizingu promatramo kao vertikalni sporazum koji sadrži vertikalna ograničenja koja mogu utjecati na trgovinu između država članica ili imaju za cilj ili posljedicu sprječavanje, ograničavanje i narušavanje tržišnog natjecanja. Stoga će one ugovorne odredbe u ugovoru o franšizingu koje sadrže spomenuta vertikalna ograničenja biti ništetne jer imaju ili mogu negativno utjecati na unutarnje tržište EU-a. ${ }^{8}$

Postojeća pravila europskoga prava tržišnog natjecanja kod ugovora o franšizingu dopuštaju puno veći broj i opseg vertikalnih ograničenja u odnosu na druge vertikalne sporazume (npr. ugovori o distribuciji). Povoljniji tretman ugovora

2. ugovor o trgovinskom zastupanju, 3. ugovor o franšizingu, 4. isključiva distribucija, 5. sporazumi o isključivoj kupnji, 6. selektivna distribucija, 7. sporazumi između proizvođača i nezavisnih distributera. S druge strane, u SAD-u se svi takvi odnosi svrstavaju u distribucijske metode i ne inzistira se na razgraničenju ovih pojmova. O tome detaljnije: Competition Policy and Vertical Restrains: Franchising Agreements, OECD, str. 20., dostupno na: http://www.oecd. org/competition/abuse/1920326.pdf, (22.3.2016.).

5 Postoji i iznimka od tog pravila. Vertikalne sporazume, osim poduzetnika koji nisu natjecatelji na tržištu, mogu sklopiti i poduzetnici koji jesu natjecatelji na tržištu ili određena udruženja poduzetnika koja se bave maloprodajom robe u slučaju da ispunjavaju uvjete iz toč. 3 . preambule Uredbe Komisije 330/2010 o primjeni čl. 101. st. 3. UFEU-a na kategorije vertikalnih sporazuma i usklađenog djelovanja, SL L 102, 23.4.2010., str. 270-276. (dalje: Uredba 330/2010). U odnosu na poslove franšizinga u obzir dolaze samo zabrane sporazumnog ograničavanja tržišnog natjecanja, dok se franšizna mreža dosada nije ocijenila kao vladajući položaj ili pokušaj monopoliziranja. Vidi Mlikotin-Tomić, D., Ugovor o franchisingu i pravo konkurencije, Pravo u gospodarstvu, 2000., god. 39., svezak 5., str. 57.

6 Čl. 1. toč. a. Uredba Komisije 330/2010.

7 O horizontalnim odnosima između davatelja i primatelja franšize kroz američku sudsku praksu vidi u: Block, B., M., Ridings, M., D., Antitrust Conspiracies in Franchise System After American Needle, Franchise Law Journal, Chicago, vol. 30., br. 4., 2011., str. 217.-220.

8 O tome detaljnije supra, str. 4., poglavlje 3.1., čl. 101. Ugovora o funkcioniranju Europske unije, SL [2010] C 83/01. (dalje: UFEU). 
o franšizingu, EU opravdava činjenicom, da je to jedini način kojim davatelj franšize štiti svoje interese tj. ostaje siguran da će njegova franšizna mreža očuvati identitet i ugled te da njegovi natjecatelji na tržištu neće doći do poslovnih metoda kojima se koristi u svom poslovanju' ${ }^{9}$ U kontekstu današnjih prilika na unutarnjem tržištu EU-a, potrebno je preispitati spomenuti pravni tretman ugovora o franšizingu. S jedne strane, treba utvrditi je li postojeća pravna regulativa EU sveobuhvatna tj. je li obuhvatila sve ili samo dio važnih interesa davatelja franšize (sva prava intelektualnog vlasništva ili samo know-how). S druge strane, potrebno je provjeriti treba li u cilju daljnjeg unaprijeđenja unutarnjeg tržišta EU-a uzeti u obzir i interese primatelja franšize kao slabije ugovorne strane i kakve bi to imalo posljedice na tržišno natjecanje EU-a? U poglavljima koja slijede rad se bavi sustavnom analizom normativnog okvira EU-a radi odgovora na navedena pitanja.

U nastavku rada daje se pregled relevantne pravne stečevine $\mathrm{u}$ odnosu na ugovor o franšizingu.

\section{PRAVNA STEČEVINA EU-A}

Radi preglednosti daljnjih izlaganja potrebno je najprije ukazati na pravila europskog prava tržišnog natjecanja koja se tiču ugovora o franšizingu. S obzirom na to da bi iscrpnija analiza prelazila granice ovog rada u ovom poglavlju daje se samo kratak prikaz relevantne pravne stečevine u odnosu na regulaciju vertikalnih sporazuma i prakse Suda EU-a koja se neposredno odnosi na ugovor o franšizingu.

\section{1. Članak 101. UFEU-a}

Polazna je točka za analizu ugovora o franšizingu u kontekstu europskog prava tržišnog natjecanja članak 101. UFEU-a ${ }^{10}$. Za njegovu primjenu na ugovor o

9 Goyder, J., EU Distribution Law, Oxford-Portland, Oregon, 2005., str. 149., (dalje: EU Distribution Law).

10 OPĆA ZABRANA

1. Sljedeće je zabranjeno kao neusklađeno zajedničkom tržištu: svi sporazumi među poduzetnicima, odluke udruženja poduzetnika i usklađeno djelovanje koji bi mogli utjecati na trgovinu među državama članicama i koji imaju za cilj ili posljedicu sprečavanje, ograničivanje ili narušavanje tržišnog natjecanja na unutarnjem tržištu, a osobito oni kojima se:

(a) neposredno ili posredno utvrđuju kupovne ili prodajne cijene ili drugi trgovinski uvjeti;

(b) ograničuju ili nadziru proizvodnja, tržišta, tehnički razvoj ili ulaganja;

(c) vrši podjela tržišta ili izvora nabave;

(d) primjenjuju nejednaki uvjeti na istovrsne poslove s ostalim trgovinskim partnerima, čime ih se stavlja u nepovoljan položaj u odnosu na konkurenciju;

(e) sklapanje ugovora uvjetuje preuzimanjem dodatnih obveza od strane drugih stranaka koje, po svojoj naravi ili prema običajima u trgovini, nisu ni u kakvoj vezi s predmetom tih ugovora.

NIŠTETNOST

2. Svi sporazumi ili odluke zabranjeni na temelju ovog članka ništavi su. IZNIMKA OD OPĆE ZABRANE

3. Međutim, odredbe stavka 1. mogu se proglasiti neprimjenjivima u slučaju: - svakog sporazuma ili vrste sporazuma među poduzetnicima, - svake odluke ili vrste odluka udruženja 
franšizingu potrebno je kumulativno utvrditi imaju li primatelj i davatelj franšize status poduzetnika, postojanje ugovora, usklađenog djelovanja ili odluka udruženja između davatelja i primatelja franšize, koji imaju za cilj ili učinak sprječavanje, ograničavanje ili ugrožavanje tržišnog natjecanja i njihov znatan utjecaj na trgovinu između država članica EU-a. ${ }^{11}$ Ugovorne odredbe kojima se ugovaraju navedeni uvjeti u ugovoru o franšizingu su ex lege ništetne. ${ }^{12}$

Unatoč tomu, članak 101. stavak 1. UFEU-a ne primjenjuje se na ugovore o franšizingu koji su sklopljeni između malih i srednjih poduzetnika i na tzv. de minimis ugovore o franšizingu kod kojih tržišni udjel davatelja i primatelja franšize ne prelazi $15 \% .^{13}$

\subsection{Uredba $330 / 2010^{14}$}

Opća zabrana iz članka 101. stavka 1. UFEU-a nije apsolutna i može se izuzeti ako određeni ugovor o franšizingu ispunjava uvjete iz članka 101. stavka 3. UFEU-a. Osim toga, odredba članka 101. stavka 3. UFEU-a pravna je osnova za usvajanje čitavog niza uredbi o skupnim izuzećima određenih kategorija vertikalnih sporazuma koji, u slučaju ispunjenja propisanih uvjeta iz relevantnih uredbi, uživaju skupno izuzeće od primjene članka 101. stavka 1 . UFEU. ${ }^{15}$

Uredba Komisije 330/2010 primjer je takvog izuzeća. Njome se uvodi pretpostavka valjanosti vertikalnih sporazuma ako sudionici sporazuma ne prelaze prag tržišnog udjela od $30 \%$ i ako njihov međusobni sporazum ne sadrži teška ograničenja tržišnog natjecanja. ${ }^{16}$

poduzetnika, - svakog usklađenog djelovanja ili vrste usklađenog djelovanja, koji doprinose poboljšanju proizvodnje ili distribucije robe ili promicanju tehničkog ili gospodarskog napretka, a istodobno potrošačima omogućuju pravedan udio u koristi koja iz njih proizlazi te koji:

(a) tim poduzetnicima ne nameću ograničenja koja nisu nužna za postizanje ovih ciljeva;

(b) tim poduzetnicima ne omogućuju isključivanje konkurencije s tržišta s obzirom na znatan dio dotičnih proizvoda.

11 O načinu ocjene navedenih uvjeta vidi u: Pošćić, A., Zabranjeni sporazumi u europskom pravu tržišnog natjecanja, Zbornik Pravnog fakulteta Sveučilišta u Rijeci, Rijeka, 1991., vol. 32., br. 1., str. 322-328.

12 Važno je napomenuti da se ništetnost utvrđuje samo u odnosu na ugovorne odredbe koje su zabranjene, dok preostali dio ugovornih odredbi ostaje na snazi pod uvjetom da se sporne odredbe mogu odvojiti od ugovora. Vidi: Butorac Malnar, V., Pecotić Kaufman, J., Petrović, S., Pravo tržišnog natjecanja, Pravni fakultet Sveučilišta u Zagrebu, Zagreb, 2013., str. 136. (dalje: Butorac Malnar, V. i dr., Pravo tržišnog natjecanja)

13 Ibid., str. 171.

14 Vidi supra, bilj. 5.

15 O tome detaljnije: Butorac Malnar, V. i dr., Pravo tržišnog natjecanja, str. 137.

16 Komisija je donijela tri bloka sekundarnih propisa o skupnom izuzeću vertikalnih sporazuma od primjene čl. 101. UFEU-a: u razdoblju od 1.2.1989. do 31.5.2000. vrijedila je Uredba 4087/88 od 30. studenog 1988. o primjeni članka 85. stavka 3. Ugovora o EEZ na kategorije sporazuma o franšizingu, SL L 359, 28.12.1988, str. 46-52., u razdoblju od 1.6.2000. do 31.5.2010. vrijedila je Uredba 2790/1999 od 22. prosinca 1999., o primjeni članka 81. stavka 3. Ugovora o EEZ na kategorije vertikalnih sporazuma i usklađena djelovanja SL L 336, 29.12.1999., str. 21-25. i u razdoblju od 1.6.2010. do 31.5.2022. vrijedit će Uredba 330/2010 (vidi supra, bilj. 5). 
Kako je već u pojmovnom određenju navedeno, ugovor o franšizingu vertikalni je sporazum koji u sebi sadrži i dodatne odredbe o ustupanju ili korištenju prava intelektualnog vlasništva gdje ustupanje tih prava nije primarni cilj zbog kojeg se sklopio ugovor. ${ }^{17}$ Iako sam tekst Uredbe 330/2010 to izrijekom ne spominje, Smjernice o vertikalnim ograničenjima koje ju prate izrijekom navode da se Uredba 330/2010 primjenjuje i na ugovor o franšizingu.$^{18}$ Time je Komisija jasno dala do znanja da joj je ideja vodilja bila pod polje primjene Uredbe 330/2010 podvesti ugovor o franšizingu kako bi se prenošenjem prava intelektualnog vlasništva i know-howa ostvarila svrha ugovora o franšizingu i doprinijelo razvoju malog i srednjeg poduzetništva. U tom slučaju davatelj franšize ima opravdanje za nametanje vertikalnih ograničenja koja bi inače po redovitom tijeku stvari bila zabranjena sukladno članku 101. stavku 1. UFEU. ${ }^{19}$

Ocjena dopustivosti nekoga vertikalnog ograničenja kod ugovora o franšizingu provodi se u nekoliko koraka. U prvom koraku potrebno je utvrditi tržišni udjel, i davatelja i primatelja franšize. Ako je tržišni udjel svakog od njih zasebno (oprez: više ne kumulativno) manji od $30 \%$ te ako ugovor o franšizingu ne sadrži teška ograničenja tržišnog natjecanja (članak 4. Uredbe 330/2010) i ograničenja koja se ne mogu izuzeti (članak 5. Uredbe 330/2010) ${ }^{20}$, takav je ugovor u potpunosti valjan sa stajališta pravila europskog prava tržišnog natjecanja. ${ }^{21} \mathrm{U}$ suprotnom, ako su

17 Vidi preambula toč. 3. i čl. 2. st. 3. Uredbe 330/2010.

18 Smjernice o vertikalnim ograničenjima §189-191, SL C 130, 19.05.2010., str. 1-46.

19 O vertikalnim ograničenjima kod ugovora o franšizingu u američkom pravu tržišnog natjecanja vidi u: Joseph, R. T., Antitrust Law, Franchising, and Vertical Restrains, Franchise Law Journal, Chicago, vol. 31., br. 1., 2011.

20 U čl. 4. Uredbe 330/2010 naveden je popis teških ograničenja tržišnog natjecanja koja isključuju pogodnost skupnog izuzeća jer imaju cilj koji je suprotan pravilima tržišnoga natjecanja. Analizom navedenoga članka proizlazi da se u odnosu na ugovor o franšizingu mogu pojaviti sljedeća teška ograničenja tržišnog natjecanja koja isključuju mogućnost skupnog izuzeća: 1. nametanje fiksnih $\mathrm{i} / \mathrm{ili}$ minimalnih prodajnih cijena davatelja franšize, 2. ograničavanjem područja i/ili korisnika na kojem primatelj franšize može prodavati robu i usluge koje su predmet sporazuma o franšizingu, osim ako nije riječ o zaštiti prenesenih prava intelektualnog vlasništva, know-howa, ugleda i identiteta franšizne mreže (supra, poglavlje 4.1., str. 13.), 3. u slučaju organiziranja franšizne mreže kao sustava selektivne distribucije teško ograničenje bilo bi ograničavanje aktivne i pasivne prodaje krajnjim korisnicima za distributere selektivne distribucije, 4. ograničavanje slobode primatelja i davatelja franšize (koji su u svojstvu distributera) u franšiznom sustavu organiziranom kao selektivna distribucija da prodaju robu ili kupuju od drugih distributera u okviru distribucijske/franšizne mreže (tzv. cross-supply), tj. prisiljavanje da kupuju samo od davatelja franšize ili osoba koje on odobri, 5. ograničavanje prava davatelja franšize kao dobavljača da prodaje rezervne dijelove krajnjim korisnicima ili serviserima ili drugim pružateljima usluga koje primatelj franšize nije ovlastio za popravak ili servisiranje svojih proizvoda.

21 Glavna novost koja je uvedena Uredbom 330/2010 jest da se sada traži da osim tržišnog udjela davatelja franšize i tržišni udjel primatelja franšize ne smije biti veći od $30 \%$. Proizlazi da će se izuzeće predviđeno čl. 2. Uredbe 330/2010 primjenjivati pod uvjetom da tržišni udjel davatelja franšize na mjerodavnom tržištu na kojem prodaje robu ili usluge, koji su predmet sporazuma nije veći od $30 \%$, a tržišni udjel primatelja franšize na mjerodavnom tržištu na kojem kupuje robu ili usluge koji su predmet ugovora o franšizingu nije veći od $30 \%$. Takav stav posljedica je utvrđenja da će u slučajevima kada tržišni udjel svakoga od poduzetnika sudionika sporazuma 
tržišni udjeli za svakog posebno veći od 30\% i ako ugovorne odredbe sadrže teška ograničenja tržišnog natjecanja ili ograničenja koja se ne mogu izuzeti, pretpostavlja se da takve odredbe potpadaju pod članak 101. stavak 1. UFEU-a i ex lege su ništetne. No i tu je ostavljena mogućnost da stranke ugovora o franšizingu dokažu pozitivne učinke na tržišno natjecanje temeljem članka 101. stavka 3. UFEU-a pa te odredbe ne bi bile ništetne. ${ }^{22}$

Ako su tržišni udjeli veći od $30 \%$ i ako ne sadrže teška ograničenja i ograničenja koja se ne mogu izuzeti, prelazi se na drugi korak u kojem se ispituje primjenjuje li se na konkretni ugovor o franšizingu članak 101. stavak 1. UFEU-a. Za tu ocjenu odlučne su sljedeće činjenice: vrsta ugovora, tržišni položaj stranaka ugovora i njihovih natjecatelja, tržišni položaj kupca koji su predmet ugovora, prepreke za ulazak na tržište, zrelost tržišta, vrsta proizvoda i usluge, razina tržišta i sl. ${ }^{23}$

Utvrdi li se navedenim testom da predmetni ugovor o franšizingu ipak ne ispunjava uvjete iz Uredbe 330/2010, strankama je ostavljena i treća mogućnost izuzeća njihova ugovora neposredno na temelju članka 101. stavka 3. UFEU-a. Tada će stranke morati dokazati da njihov ugovor o franšizingu dovodi do objektivnih ekonomskih koristi, odnosno da je konkretno ograničenje tržišnog natjecanja potrebno za postizanje učinkovitosti, kao i da potrošači imaju pravedan udio u dobicima od ekonomičnosti i da im njihov ugovor ne omogućuje isključivanje tržišnog natjecanja u odnosu na značajan dio dotičnih proizvoda. ${ }^{24}$

\subsection{Praksa Suda EU-a}

Ugovor o franšizingu u kontekstu europskog prava tržišnog natjecanja valja promatrati zajedno s pravnom stečevinom koja se tiče drugih vertikalnih sporazuma, a osobito ugovora o distribuciji. S obzirom na to da je praksa Suda EU-a u odnosu na ugovor o distribuciji (koja se na odgovarajući način primjenjuje i na ugovor o franšizingu) bila predmetom brojnih radova u domaćoj pravnoj literaturi, u nastavku se analiziraju samo presude Suda EU-a u kojima se neposredno raspravljalo o ugovoru o franšizingu, a koje do sada nisu bile predmetom analize u domaćoj pravnoj literaturi.

ne premašuje $30 \%$ na mjerodavnom tržištu i ako njihovi vertikalni sporazumi ne sadrže teška ograničenja tržišnog natjecanja, imati za posljedicu poboljšanje u proizvodnji ili distribuciji, a potrošačima ponuditi pravedan dio u tako ostvarenoj koristi. Usp. tekst Uredbe 330/2010 i Uredbe 2790/1999.

22 Butorac Malnar, V. i dr., Pravo tržišnog natjecanja, str. 171.

23 Smjernice o vertikalnim ograničenjima $\S 111$.

24 Smjernice o vertikalnim ograničenjima § 122. Sukladno Uredbi Vijeća (EZ) br. 1/2003 od 16. prosinca 2002. o provedbi pravila o tržišnom natjecanju koja su propisana člancima 81. i 82. Ugovora o EZ-u (tekst značajan za EGP), SL L 1, 4.1.2003., od str. 1-25., (dalje: Uredba Vijeća 1/2003), svi sporazumi koji ispunjavaju uvjete iz čl. 101. st. 3. valjani su i nije potrebna posebna odluka Komisije kojom bi se to potvrdilo (tzv. legal exception system). Vidi: Butorac Malnar, V. i dr., Pravo tržišnog natjecanja, str. 137. i 140. 
Riječ je o dvije presude u predmetima Pronuptia ${ }^{25}$ i La Retoucherie. ${ }^{26}$

Prva i ujedno najvažnija presuda u kojoj se neposredno raspravljalo o ugovoru o franšizingu donesena je osamdesetih godina prošloga stoljeća u predmetu Pronuptia. ${ }^{27}$ Spomenuta presuda izazvala je snažne reakcije u stručnoj i akademskoj javnosti i pridonijela je otvaranju niza pravnih pitanja, a sve daljnje odluke Komisije i nacionalnih tijela za zaštitu tržišnog natjecanja dobile su uporište za donošenje i tumačenje odluka kojima su se zabranjivale pojedine odredbe i/ili čak cijeli ugovori o franšizingu. ${ }^{28}$

Slijedeći spomenute smjernice dane u predmetu Pronuptia, Komisija je donijela niz odluka vezanih uz ugovore o franšizingu ${ }^{29}$, a kao konačan rezultat 1988. uslijedilo je donošenje Uredbe 4087/88 o skupnom izuzeću kategorija ugovora o franšizingu koja je ostala u primjeni sve do 2000 . godine..$^{30}$

Sudska i normativna aktivnost institucija EU-a rezultirale su i stanovitim promjenama u franšiznoj poslovnoj praksi i trgovačkim običajima između stranaka ugovora o franšizingu. Naime, prestale su se ugovarati ne samo zabranjene ugovorne odredbe (npr. nametanje fiksnih i minimalnih cijena roba i usluga), već i potencijalno zabranjene ugovorne odredbe (npr. ugovaranje isključivih prava na određenom tržištu, obveza poslovanja samo s određenim kupcima, itd.).

\subsubsection{Predmet Pronuptia}

Najvažnija odluka u kojoj je Sud EU-a neposredno tumačio europsko pravo tržišnog natjecanja u odnosu na ugovor o franšizingu odluka je u predmetu Pronuptia iz 1986. godine. Tom odlukom stvoreni su jasni kriteriji prema kojima je moguće

25 Predmet 161/84, Pronuptia de Paris GmbH v. Irmgard Schillgalis (1986), ECR (dalje: predmet Pronuptia). U radu se u pogledu odluke Komisije u predmetu Pronuptia izrijekom navodi da je riječ o odluci Komisije, za sve ostale slučajeve gdje to nije izrijekom navedeno, misli se na presudu Europskog suda u predmetu Pronuptia.

26 Predmet C-117/12, La Retoucherie de Manuela v. La Retoucherie de Burgos (dalje: predmet La Retoucherie), sažetak presude dostupan na engleskom jeziku u SL C 108, 7.2.2013., str. 8.-9. Za potrebe rada korištena španjolska verzija teksta koja sadrži puni tekst presude Europskog suda, dostupno na: http://curia.europa.eu/juris/document/document_print. jsf?doclang $=\mathrm{ES} \&$ text $=\&$ pageIndex $=0 \&$ part $=1 \&$ mode $=1$ st $\&$ docid $=133891 \&$ occ $=$ first $\&$ dir $=$ $\&$ cid $=671186$ (23.3.2016.).

27 U svom dosadašnjem sudovanju Europski sud donio je samo dvije odluke koje se neposredno odnose na ugovor o franšizingu. Do tada je ova materija promatrana kroz analogiju s drugim srodnim ugovorima, najčešće ugovorom o distribuciji. Vidi: EU Distribution Law, str. 149.

28 O povijesti razvoja pravne stečevine koja se neposredno tiče ugovora o franšizingu vidi: http:// www.unidroit.org/english/guides/2007franchising/country/eu.pdf (31.3.2016.).

29 Vidi: Odluka Komisije 87/14/EEC u predmetu Yves Rocher, od 17. prosinca 1986., SL L 8/49, 10.1.1987., SL L 8 10.1.1987., (dalje: odluka Yves Rocher); Odluka Komisije 87/17/EEC u predmetu Pronuptia, od 17. prosinca 1986., SL 13/39, 15.1.1987., (dalje: odluka Komisije Pronuptia); Odluka Komisije 87/407 u predmetu Computerland od 13. srpnja 1987., SL L 222/12, 10.8.1987., (dalje: odluka Computerland); Odluka Komisije 88/604 u predmetu Service Master od 20. kolovoza 1988., SL L 332/38, 3.12.1988. (dalje: odluka Service Master) i Odluka Komisije 89/94/EEC u predmetu Charles Jourdan od 2. prosinca 1988., SL L 35/31, 7.1.1989. (dalje: odluka Charles Jourdan).

30 Uredba 4087/88, supra. bilj. 14. 
dopustiti izuzeća ugovora o franšizingu od jedinstvene primjene članka 85. Ugovora o EEZ-u (današnji članak 101. UFEU-a). ${ }^{31}$

Radi preglednosti u razradi problematike u nastavku rada daje se prikaz relevantnog činjeničnog stanja u predmetu Pronuptia.

U predmetu su stranke Pronuptia de Paris GmbH (davatelj franšize) ${ }^{32}$ i gospođa Shillgalis (primateljica franšize) sklopili ugovor o franšizingu kojim je primateljica franšize stekla pravo korištenja franšize Pronuptia de Paris na području Hamburga, Oldenburga i Hanovera u zamjenu za plaćanje franšizne naknade. ${ }^{33}$ Nakon nekog vremena davatelj franšize tužio je primateljicu franšize radi isplate zaostalih franšiznih naknada za razdoblje od 1978. do 1980. godine. ${ }^{34}$

Cijeli slučaj završio je u prethodnom postupku pred Sudom EU-a radi tumačenja pravila europskog prava tržišnog natjecanja u odnosu na predmetni ugovor i procjenu njegove valjanosti. Sporne ugovorne odredbe sa stajališta prava tržišnog natjecanja odnosile su se na obvezu primateljice da nabavlja najmanje $80 \%$ robnih zaliha od davatelja franšize, a ostatak samo od dobavljača koje odobri davatelj franšize, zatim na obvezu primateljice franšize da surađuje s davateljem franšize oko oglašavanja

31 Tako i: Hurley, E., R., Pronuptia de Paris vs. Schillgalis: Permissible Restrants of Trade on Franchising in the EEC, Northwestern Journal of International Law \& Business, Chicago, vol. 8., br. 2., 1987., str. 476-477.

32 Davatelj franšize, Pronuptia de Paris $G m b H$, bio je osnovan kao njemačko društvo-kćer u vlasništvu poznatog francuskog brenda vjenčanica i vjenčane opreme Pronuptia de Paris iz Pariza. Ono je na području Njemačke poslovalo na dva načina: ili kao distributer vjenčanica i pripadajuće vjenčane opreme i/ili kao davatelj franšize Pronuptia de Paris $\mathrm{GmbH}$ sklapanjem ugovora o franšizingu s nezavisnim njemačkim trgovcima. Vidi predmet Pronuptia, $\S 3$.

33 Osim toga primateljica franšize predmetnim ugovorom stekla je i pravo korištenja tvrtke i robnog žiga Pronuptia de Paris na ugovorenim područjima u Njemačkoj, kao i pravo kontinuiranog pružanja pomoći i savjeta davatelja franšize u raznim aspektima vođenja poslovanja.

34 Prvostupanjski sud usvojio je zahtjev tužitelja naloživši tuženici isplatu zaostalih franšiznih naknada u iznosu od 158502 njemačkih maraka za razdoblje od 1978. do 1980. godine. Davateljica franšize uložila je žalbu na spomenutu presudu njemačkom drugostupanjskom sudu tvrdeći da je presuda neosnovana jer je predmetni ugovor o franšizingu suprotan čl. 85. i Uredbi Komisije 67/67/EEC od 22. ožujka 1967. o primjeni članka 85. stavka 3. Ugovora o EEZ na određene kategorije sporazuma o isključivoj kupnji (engl. exclusive dealing), SL 57, 25.3.1967, str. 849-852.) i stoga zabranjen. Drugostupanjski sud prihvatio je argumente primateljice franšize tvrdeći da međusobne isključive obveze predstavljaju ograničenja unutarnjeg tržišta jer davatelj franšize nije smio opskrbljivati robom Pronuptia de Paris druge trgovce na ugovorenom području, a primateljica franšize je smjela kupovati i prodavati robu drugih marki samo u ograničenom opsegu. S obzirom na to da nisu ispunjeni uvjeti za izuzeće od opće zabrane sukladno čl. 85. st. 3. Ugovora o EU, predmetni ugovori proglašeni su ništetnima. U odnosu na pitanje jesu li ugovori o franšizingu općenito isključeni od polja primjene Uredbe 67/67/EEC njemački je sud zaključio da ugovori predstavljaju poduzetnike koji nadilaze one opisane u čl. 1.67/67/EEC i stoga predstavljaju povredu tržišnog natjecanja koja nije pokrivena čl. 2. Uredbe 67/67/EEC. Tužitelj se na drugostupanjsku presudu žalio njemačkom Saveznom vrhovnom sudu koji je na kraju pokrenuo prethodni postupak pred Europskim sudom radi tumačenja prava tržišnog natjecanja EU-a. Vidi predmet Pronuptia, § 7. i 8. O činjeničnom stanju predmeta Pronuptia pred njemačkim nacionalnim sudovima detaljnije u: Hurley, E., R., Pronuptia de Paris vs. Schillgalis: Permissible Restrants of Trade on Franchising in the EEC, Northwestern Journal of International Law \& Business, Chicago, vol. 8., br. 2., 1987., str. 480482 . 
i korištenja promotivnih materijala na kojima su bile otisnute preporučene cijene, obvezu primateljice franšize da se ne natječe s davateljem franšize na području tadašnje Zapadne Njemačke godinu dana nakon isteka predmetnog ugovora, kao i zabranu ustupanja predmetne franšize trećim osobama bez pristanka davatelja franšize. ${ }^{35}$

Jedna je od najvažnijih poruka iz predmeta Pronuptia da se članak 85. stavak 1. Ugovora o EZ-u (današnji članak 101. UFEU-a) ne primjenjuje jednako na sve ugovore o franšizingu, već se treba procjenjivati od slučaja do slučaja, tj. s obzirom na konkretno činjenično i pravno stanje te ekonomski kontekst u kojem se nalazi (dalje: case by case metoda). Određena ugovorna ograničenja unutar franšiznog sustava koja je nametnuo davatelj franšize po prirodi su nerazdvojna od samog ugovora i kao takva ne predstavljaju povredu članka 85. stavka 1. Ugovora o EEZ-u (današnji članak 101. stavak 1. UFEU-a). Osim toga, naglašeno je da određene vrste ugovornih odredbi, koje ograničavaju radnje primatelja franšize (npr. odredbe o cjenovnim ograničenjima, podjelama tržišta i trajna zabrana obavljanja iste djelatnosti nakon prestanka ugovora o franšizingu) nisu dopuštene ni pod kojim uvjetima i u svakom slučaju predstavljaju povredu europskih pravila tržišnog natjecanja. ${ }^{36}$

Ako navedeni stav Suda EU-a testiramo u današnjim okolnostima na unutarnjem tržištu EU-a, proizlazi da ga treba prihvatiti s velikom dozom opreza. Naime, opravdano je stajalište Suda EU-a kada kaže da davatelju franšize, s obzirom na prirodu samog ugovora o franšizingu, treba omogućiti da zaštiti interese koji su presudni za franšizno poslovanje i za identifikaciju njegove franšizne mreže (npr. know-how). ${ }^{37}$ Ipak, nakon niza godina vođenja pozitivne politike EU-a u odnosu na ugovor o franšizingu, određena vertikalna ograničenja su se standardizirala i počela univerzalno primjenjivati bez obzira na ekonomski i pravni kontekst u kojem posluje franšizna mreža. To je dovelo do toga da su se davatelji franšize počeli lukavo koristiti pogodnostima europskih pravila tržišnog natjecanja i nametati prevelika vertikalna ograničenja kojima štite spomenute interese $\mathrm{e}^{38}$. Stoga se danas treba inzistirati na case by case metodi i strožim kriterijima pri ocjeni dopustivosti spomenute zaštite jer prevelika sloboda davatelja franšize može poslužiti kao platforma za legitimnu zloupotrebu. Ovu tezu potkrjepljuje i činjenica da se u trenutku donošenja presude u predmetu Pronuptia vrlo pozitivno gledalo na ugovor o franšizingu, jer je u tim vremenima njegova sustavna analiza u potpunosti zaostajala za razvijenim američkim tržištem. Stoga se nastojalo izaći u susret davateljima franšize kako bi se razvio ovaj oblik poslovanja i europsko tržište približilo prilikama koje su vladale na američkom

35 op. cit., str. 155, EU Distribution Law.

36 Ibid.

37 „Sustav ugovora o franšizingu kao vrsta distribucije roba dopušta davatelju franšize da stekne financijsku dobit na temelju poslovnih metoda i ugleda trgovačkog imena, ne predstavlja sama po sebi povredu tržišnog natjecanja. Podudarnost takvog ugovora o franšizingu s čl. 101. st. 1. UFEU-a ne može se ocjenjivati općenito, već se prosuđuje na temelju ugovorenih odredbi u svakom pojedinom ugovoru o franšizingu i ekonomskom kontekstu.“, Vidi: predmet Pronuptia, $\S 27$. Detaljnije o tome vidi u: Braun, W. D., Ritter, L., EC Competition Law: a practicioner's guide, Kluwer Law International, Den Haag, 2000., III. izdanje, str. 263-380.

38 Crafword Spencer, E., The Regulation of Franchising in the New Global Economy, Edward Elgar Publishing Limited, Cheltenham, 2010., str. 11. 
tržištu. Takav stav trenutno nije u potpunosti održiv jer može ugroziti tržišno natjecanje na tržištu primatelja franšize. ${ }^{39}$

Kao odgovor na novonastalu situaciju predlaže se korištenje strožih kontrola pri ocjeni neophodnosti pojedinih vertikalnih ograničenja kojima se štite interesi davatelja franšize. Osim toga, pri donošenju novoga bloka uredbi o skupnim izuzećima, Komisija bi trebala razmišljati kako prevenirati buduće probleme, a ne samo kako odgovoriti na postojeće zahtjeve tržišta. U tom smislu trebalo bi proučavati sadržaje tipiziranih ugovora o franšizingu i pravila savjetodavnih tijela koja pripremaju vodiče i model zakone ${ }^{40}$ i pokušati iščitati pravne posljedice pojedinih ugovornih odredbi. Time bi mogla djelovati preventivno i spriječiti negativan utjecaj na unutarnje tržište EU-a.

\subsubsection{Predmet La Retoucherie}

Drugi predmet u kojem se Sud EU-a neposredno bavio ugovorom o franšizingu je predmet La Retoucherie. U navedenom predmetu španjolski sud zatražio je tumačenje i opseg primjene formulacije poslovni prostor i zemlja koji su se koristili u Uredbi 2790/1999, koja je prethodila trenutno važećoj Uredbi 330/2010 ${ }^{41}$. Naime, nije bilo jasno odnosi li se zabrana natjecanja nakon prestanka ugovora o franšizingu samo na poslovne prostore i zemljište u kojima je poslovao primatelj franšize ili se treba tumačiti ekstenzivno u smislu da se zabrana natjecanja odnosi na čitavo područje ili čak na čitavu državu članicu EU-a unutar koje je vrijedio ugovor o franšizingu.

Spor je pokrenut pred španjolskim nacionalnim sudom u postupku između $L a$ Retoucherie de Manuela (davatelja franšize) i La Retoucherie de Burgos (primatelja franšize) koji su sklopili ugovor o franšizingu o pružanju krojačkih usluga u trajanju od pet godina. Ugovor je sadržavao zabranu natjecanja prema kojoj je primatelju franšize bilo zabranjeno pružati iste ili slične radnje, poput onih iz ugovora na bilo kojem području koje pokriva ugovor tijekom trajanja i godinu dana nakon prestanka ugovora bez obzira na razlog prestanka. ${ }^{42}$

39 Osim toga, na vidjelo su počele izlaziti i manjkavosti u regulaciji ove materije o kojima se preventivno nije vodilo računa. Primjerice, primatelj franšize može steći pravo na novonastale oblike intelektualnog vlasništva do kojih je došao za vrijeme trajanja ugovora o franšizingu jer je prema dosadašnjim pravilima propisana samo obveza povrata novonastalog know-howa. (Infra poglavlje 4. 1. B).

40 Npr. UNIDROIT (puni naziv na hrvatskom: Međunarodni institut za unifikaciju privatnog prava) Guide to International Master Franchise Arrangements, Rim, 2007., dostupno na engleskom jeziku: http://www.unidroit.org/english/guides/2007franchising/franchising2007guide-2nd-e.pdf (1.7.2016.). O UNIDROIT vidi bilj. 63.

41 Vidi čl. 5. b. Uredbe 2790/1999 (supra bilj. 14). Ova presuda vrlo je važna jer, iako se odnosi na staru Uredbu 2790/1999, nova Uredba 330/2010 ima gotovo isto uređenje. Članak 5. b. Uredbe 2790/1999 primjenjivao se na postugovornu odgovornost samo u mjeri u kojoj je takva postugovorna obveza ograničena na poslovni prostor iz kojeg i zemlju iz koje je kupac djelovao za vrijeme trajanja ugovora, a u novoj Uredbi 330/2010 uz navedeno postoji samo dodatak da se takva postugovorna odgovornost može ugovoriti najduže na godinu dana u slučaju da ima za cilj zaštititi povjerljive informacije.

42 Svrha ugovorne odredbe bila je zaštititi know-how i stručnost. U slučaju kršenja ove odredbe bila je ugovorena ugovorna kazna u iznosu većem od 90000 eura. Nakon što je primatelj 
Sud EU-a presudio je da se formulacija poslovni prostor ili zemlja treba tumačiti restriktivno, tj. u skladu s općeprihvaćenim shvaćanjem. Zaključeno je da se takva formulacija odnosi samo na fizički prostor kao dio zgrade, a zemlja predstavlja parcelu kao dio zemljišta, a ne cijelo područje i državu koje je povjereno primatelju franšize ${ }^{43}$. Kao opravdanje takvom stavu Suda EU-a naveo je da se riječ područje koristila posvuda u Uredbi 2790/1999 i stoga je bila očita namjera Komisije razgraničiti ove dvije riječi i njihovo značenje.

Ako presudu testiramo u trenutnim okolnostima proizlazi da i u današnjem kontekstu ima isto značenje. Prihvatljivo je stajalište Suda EU da se u odnosu na druga područja na kojima se nije doista odvijalo franšizno poslovanje, tj. stvarna prodaja franšizne robe i usluga, ne mogu primijeniti pogodnosti iz Uredbe 330/2010. Stoga ni danas nije dopušteno ugovoriti zabranu natjecanja na cjelokupnom području na kojem je vrijedio ugovor jer bi ona bila protivna pravilima o europskom pravu tržišnog natjecanja. Postugovorne zabrane natjecanja trebaju se odnositi samo na poslovne prostore i/ili parcele u kojim je franšiza korištena tijekom trajanja ugovora. Ovo stajalište temelji se na tezi da se vertikalna ograničenja smiju nametnuti samo ako su neophodna za zaštitu franšizne mreže. Stoga je dopuštena samo ona zabrana koja je ograničena isključivo na poslovni prostor ili zemljište (parcelu) iz kojeg je primatelj djelovao za vrijeme trajanja ugovora o franšizingu i pod uvjetom da je ona neophodna za zaštitu prenesenog know-howa.

Drugi problem na koji se treba osvrnuti, a koji nije neposredno obrađen u predmetu La Retoucherie, jest trajanje zabrane natjecanja. Uredbom 330/2010 propisano je da može trajati najduže jednu godinu nakon prestanka ugovora o franšizingu ${ }^{44}$ Taj se rok u većini ugovora primjenjuje univerzalno iako to nije bila namjera Komisije pri donošenju Uredbe 330/2010. Stoga, pri ugovaranju vertikalnog ograničenja, koje se tiče zabrane natjecanja, treba voditi računa da rok od godinu dana nije univerzalan, već ga se treba odrediti ovisno o konkretnom ekonomskom i pravnom kontekstu. U nekim je franšiznim mrežama ugovaranje najdužeg roka od jedne godine nepotrebno i može se zlorabiti, dok je u drugima rok od godine dana primjeren i nužan. ${ }^{45}$

franšize jednostrano raskinuo ugovor i zahtijevao da se zanemari odredba o zabrani natjecanja, davatelj franšize ga je tužio za naknadu štete zbog prijevremenog raskida ugovora $\mathrm{i}$ isplatu ugovorne kazne zbog kršenja postugovorne odgovornosti o zabrani natjecanja. Vidi: predmet La Retoucherie, $\S 9$.

43 Ibid., predmet La Retoucherie § 29.

44 Usp. čl. 5. Uredbe 330/2010.

45 Primjerice, nije potrebno ugovoriti isti rok zabrane natjecanja kod primatelja svjetski poznatog i lokalnog lanca brze hrane. Kod svjetski poznatog lanca brze prehrane kupci neće doći u zabludu jer je prepoznatljivost franšizne mreže (npr. McDonald's okus hamburgera, izgled poslovnih prostora i sl.) ono što ih motivira za kupnju određenog proizvoda. S druge strane, kod lokalnog lanca brze prehrane kupci bi lakše mogli doći u zabludu i poistovjetiti primatelja franšize s davateljem franšize. $U$ tom slučaju primatelj franšize koji nakon kratkog vremena pokrene vlastiti lanac brze prehrane lakše bi doveo u zabludu kupce i mogao nepošteno steći tržišnu prednost. 


\section{PREGLED DOPUŠTENIH I ZABRANJENIH UGOVORNIH ODREDBI IZMEĐU DAVATELJA I PRIMATELJA FRANS̆IZE}

U nastavku se daje sveobuhvatan pregled dopuštenih i zabranjenih ugovornih odredbi u vertikalnom odnosu između davatelja i primatelja franšize. Prvu skupinu čine ugovorne odredbe koje su nužne za zaštitu prava intelektualnog vlasništva, knowhowa, identiteta/ugleda franšizne mreže. ${ }^{46}$ Drugu skupinu čine apsolutno zabranjene ugovorne odredbe.

Pregled obuhvaća postojeću pravnu regulativu, praksu Suda EU-a i odluke Komisije koje se neposredno tiču ugovora o franšizingu. Usporedno se daje kritički osvrt na neke od njih jer se doslovnim tumačenjem gubi smisao njihovog ugovaranja, a samim time postavlja se i pitanje pravne valjanosti sa stajališta pravila europskog prava tržišnog natjecanja. Napominje se da ova klasifikacija nije taksativna i da se pojedine odredbe mogu premještati iz jedne skupine u drugu ovisno o činjeničnom i pravom stanju stvari, kao i o ekonomskom kontekstu ugovora o franšizingu. ${ }^{47}$

\subsection{Dopuštene ugovorne odredbe kod ugovora o franšizingu}

Zaštita prava intelektualnog vlasništva i ugleda/identiteta franšizne mreže imala je za posljedicu oblikovanje karakterističnih ugovornih odredbi kod ugovora o franšizingu. ${ }^{48} \mathrm{Sa}$ stajališta europskoga prava tržišnog natjecanja takve odredbe dopuštene su sve dok se njima postiže svrha zaštite, a sve preko te granice smatra se zabranjenim. Stoga je poslovna zajednica sa zanimanjem pratila pravnu regulativu, relevantne odluke Komisije i Suda EU-a te sukladno njima mijenjala sadržaj ugovora o franšizingu. Time su se nastojale izbjeći pravne posljedice ništetnosti u slučaju ugovaranja odredbi koje su suprotne kogentnim pravilima EU-a i njihovim tumačenjima.

Iz relevantne pravne stečevine EU-a i prilika na zajedničkom tržištu proizlazi da je, u slučaju razilaženja u tumačenjima između Komisije i Suda EU-a, često praktičnije i ekonomičnije slijediti stavove Komisije. Uporište za takav stav utemeljeno je na nekoliko zapažanja. Komisija je, za razliku od Suda EU-a, kroz povijest u pravilu puno strože tretirala vertikalna ograničenja $\mathrm{i}$ češće ih proglašavala zabranjenima. $\mathrm{S}$

46 Takva podjela korištena je i u predmetu Pronuptia, Uredbi 330/2010 i Smjernicama o vertikalnim ograničenjima. Sličnu podjelu u nešto suženijem opsegu koristi i EU Distribution Law, str. 156-172. U radu je ova posljednja podjela aktualizirana i proširena.

47 Vidi premet Pronuptia, § 27.

48 Ugovor o franšizingu najčešće počinje preambulom u kojoj se navode podatci o strankama, namjere i osnovni pojmovi koji će se koristiti u ugovoru. Odredbe se mogu podijeliti u tri skupine: koje se odnose na sklapanje ugovora, koje opisuju prava i obveze stranaka tijekom trajanja pravnog odnosa i koje predviđaju uvjete i način raskida ugovora. Ove odredbe u pravilu su preporučeni sadržaj svakog ugovora o franšizingu: pravila pristupanja u sustav franšizinga, trajanje ugovora, područje rada (djelatnost) primatelja franšizinga, prava i obveze stranaka, zaštita robnih marki i oznaka, zaštita poslovnih tajni, zabrana natjecanja, obuka, cijena licence i naknada za marketing promocija i marketing, upravljačka prava davatelja franšizinga, raskid ugovora. Ta su pitanja definirana i Etičkim kodeksom Europske franšizne federacije, dostupno na: http://www.franchise-fff.com/base-documentaire/finish/206/327.html (23.3.2016.). 
druge strane, odluke Komisije, kao nižeg procesnog tijela od Suda EU-a, u većini su slučajeva konačne jer se malo poduzetnika zbog dugotrajnosti i visine troškova odluči pokrenuti spor pred Sudom EU-a protiv odluka Komisije. ${ }^{49}$ Također, Komisija kao tzv. europski zakonodavac donosi većinu uredbi i smjernica za njihovo tumačenje. Iako te smjernice nemaju obvezni karakter, prešutno je pravilo da ih državna tijela i nacionalni sudovi dosljedno primjenjuju.

\subsubsection{Ugovorne odredbe o zaštiti prava intelektualnog vlasništva}

Vertikalna ograničenja kojima se štite prava intelektualnog vlasništva kod ugovora o franšizingu nisu sama po sebi dopuštena. Za ocjenu njihove valjanosti Uredba 330/2010 u članku 2. stavku 3. zahtijeva kumulativno ispunjenje sljedećih pet uvjeta: odredbe o pravima intelektualnog vlasništva moraju biti sastavni dio ugovora o franšizingu, prava intelektualnog vlasništva moraju biti ustupljena ili dana na korištenje primatelju franšize, odredbe o pravima intelektualnog vlasništva ne smiju predstavljati osnovni cilj ugovora o franšizingu, odredbe o pravima intelektualnog vlasništva moraju se neposredno odnositi na korištenje, prodaju ili daljnju prodaju robe ili usluga primatelja franšize ili njegovih naručitelja, odredbe o intelektualnom vlasništvu, koje se odnose na robu ili usluge iz ugovora, ne smiju sadržavati ograničenja tržišnog natjecanja koja imaju isti cilj kao i vertikalna ograničenja koja nisu obuhvaćena izuzećem kao što je to predviđeno Uredbom 330/2010.

Spomenuti uvjeti međusobno se nadopunjuju pa ih je potrebno analizirati kao cjelinu. Stoga ni ne čudi zahtjev Komisije koja inzistira na kumulativnom ispunjenju navedenih pet uvjeta. Time je Komisija posredno definirala bitne sastojke ugovora o franšizingu i odredila u kojem smjeru stranke moraju ispunjavati prava i obveze (osobito davatelji franšize kao jače ugovorne strane) ako žele uživati povlastice skupnog izuzeća. To je imalo za posljedicu bespogovornu prilagodbu poslovne zajednice i revidiranje bitnih sastojaka ugovora o franšizingu (standardiziranih formulara ugovora o franšizingu) na europskom području u smjeru koji je zadala Komisija. Pogodnosti skupnog izuzeća bile su dobar mamac Komisije jer bi, u slučaju ispunjenja navedenih uvjeta, davatelj franšize imao legitimno pravo, radi zaštite prenesenih prava intelektualnog vlasništva, nametnuti vertikalna ograničenja kao što su, primjerice, obveza suradnje i obavještavanja primatelja franšize ${ }^{50}$, zabrana raspolaganja prenesenim pravima $^{51}$ i prenošenja ugovora o franšizingu na treće

49 Tako i: EU Distribution Law, str. 150.

50 Odnosi se, primjerice, na obvezu primatelja franšize da obavještava davatelja franšize o potencijalnim i učinjenim povredama prenesenih prava intelektualnog vlasništva, obvezu primatelja franšize da pokrene sudski postupak protiv prekršitelja tih prava, obvezu davatelja franšize da pruži pomoć primatelju franšize u sudskim postupcima protiv prekršitelja. Vidi Smjernice o vertikalnim ograničenjima $\S 43$.

51 Davatelj franšize smije zabraniti primatelju franšize da raspolaže prenesenim pravima i obvezama iz ugovora o franšizingu bez njegova pristanka. U širem smislu dopušteno je ugovaranje prijenosa ugovora o franšizingu na nekog trećeg primatelja franšize ili davanje franšize u podfranšizu, ali uz prethodni pristanak davatelja franšize. Smjernice o vertikalnim ograničenjima § 31-45. i EU Distribution Law, str. 169. U odluci Charles Jourdan § 27., takva ugovorna odredba bila je dopuštena kako bi davatelj franšize bio siguran da primatelj franšize 
osobe bez pristanka davatelja franšize. ${ }^{52}$ Ova teza potkrjepljuje se u nastavku ovoga poglavlja iscrpnom analizom svakog spomenutog uvjeta.

Iz prvog uvjeta jasno proizlazi da se vertikalna ograničenja mogu ugovoriti samo u sklopu ugovora o franšizingu (ili eventualno drugih sporazuma o kupnji, distribuciji robe, sporazumima o kupnji ili pružanju usluga). U suprotnom, ako su ona sastavni dio sporazuma o ustupanju ili licenciranju prava intelektualnog vlasnišstva za proizvodnju robe ili sporazuma o licenciranju, ona tada ne bi bila mogla uživati pogodnosti skupnog izuzeća propisanog Uredbom 330/2010 ${ }^{53} \mathrm{i}$ bila bi zabranjena.

Uredba 330/2010 u drugom uvjetu propisuje da u ugovoru o franšizingu vertikalna ograničenja koja se tiču zaštite prava intelektualnog vlasništva smije nametnuti samo davatelj franšize primatelju franšize, ali ne i obratno. ${ }^{54}$ Spomenuto je rješenje logično jer se temelji na pojmovnom određenju ugovora o franšizingu iz kojeg proizlazi da se prijenos prava intelektualnog vlasništva uvijek vrši jednosmjerno, tj. s davatelja na primatelja franšize, ali ne i obrnuto. Ako primatelj franšize prenosi prava intelektualnog vlasništva na davatelja franšize tu nije riječ o ugovoru o franšizingu, već o drugom ugovoru u kojem dolazi samo do prijenosa prava intelektualnog vlasništva bez prijenosa ostalih dijelova franšize. Takvo stajalište potvrđeno je i u članku 2. stavak 3. Uredbe 330/2010, kojim se određuje da se skupno izuzeće primjenjuje samo na one vertikalne sporazume koji sadrže odredbe kojima se kupcu (tj. davatelju franšize) ustupaju ili daju na korištenje prava intelektualnog vlasništva, pod uvjetom da te odredbe ne čine primarni cilj takvih sporazuma. U slučaju prijenosa prava intelektualnog vlasništva s primatelja na davatelja franšize bila bi dakle riječ o ugovorima koji imaju za primarni cilj prijenos prava intelektualnog vlasništva pa stoga takvi ugovori ne uživaju zaštitu iz Uredbe 330/2010. Ako primatelj franšize, osim prava intelektualnog vlasništva, zaista prenosi i poslovne metode, tj. franšizu, tu bi se radilo o novom ugovoru o franšizingu. Tada bi primatelj franšize postao davatelj franšize, a davatelj franšize postao bi primatelj franšize. Tek tada bi se primatelj franšize, odnosno sada davatelj franšize u novom ugovoru o franšizingu, mogao pozvati na pogodnost skupnog izuzeća i to pod uvjetom da ispunjava i preostale uvjete iz članka 2. stavka 3. Uredbe 330/2010. Ukratko rečeno, postojeći uvjet ne zahtijeva proširenje i na prava intelektualnog vlasništva čiji je vlasnik primatelj franšize, a koja bi se eventualno prenosila, jer takve situacije u kojima bi se štitilo intelektualno vlasništvo primatelja franšize uopće ne bi bile dio ugovora o franšizingu, već ugovora o prijenosu prava intelektualnog vlasništva i kao takve ne bi uživale zaštitu s aspekta

ima profesionalne kompetencije potrebne za obavljanje radnih zadataka, ali i da nove osobe koje nisu do tada bile dio Charles Jourdan franšizne mreže ne dođu olako do prednosti koje imaju postojeći sudionici distribucijskog sustava. Vidi i: Odluka Yves Rocher, § 47.

52 Vidi čl. 4. i 5. Uredbe 330/2010. U pravilu svaki prijenos ugovora zahtijeva sporazum između svih stranaka: davatelja, postojećeg i novog primatelja franšize. Neki ugovori već u sebi sadrže ovlaštenje davatelja franšize da prenese svoja prava i obveze iz ugovora o franšizingu na treću stranku (pravnog slijednika). Osim toga, moguć je i prijenos poduzeća ili dionica/poslovnih udjela na primatelja franšize. Takav prijenos općenito je dopušten, ali može biti ograničen ugovornim odredbama.

53 Smjernice o vertikalnim ograničenjima $\S 33$.

54 Ibid. § 34 . 
prava tržišnog natjecanja.

Treći i četvrti uvjet potrebno je analizirati zajedno jer se neposredno nadovezuju. U njima je propisano da glavni cilj ugovora o franšizingu mora biti kupnja, prodaja ili daljnja prodaja robe ili usluga, te da odredbe koje se tiču prava intelektualnog vlasništva moraju biti samo pomoćno sredstvo za njegovu provedbu. ${ }^{55}$ Komisija navodi da prenesena prava industrijskog vlasništva trebaju samo olakšati korištenje, prodaju ili daljnju prodaju robe ili usluga primatelja franšize. Takve ugovorne odredbe bile bi one koje se odnose na plasman robe ili usluga na tržištu gdje davatelj franšize korisniku franšize prodaje robu za daljnju prodaju i ujedno mu daje licencu za korištenje njegova robnog žiga i know-howa radi što boljeg plasmana robe na tržište. ${ }^{56}$ Može se zaključiti da je EU opravdano derogiralo pravila tržišnog natjecanja i dao prednost zaštiti prava intelektualnog vlasništva koja se posredno prenose ugovorom o franšizingu. Iako je riječ o pomoćnim dijelovima ugovora, bez njihova prijenosa ugovor o franšizingu ne bi imao smisla, a njihovim otkrivanjem davatelj franšize izgubio bi prednost $\mathrm{u}$ odnosu na svoje natjecatelje jer bi oni mogli neovlašteno doći do sadržaja tih prava. Osim toga, ovi uvjeti potvrđuju tezu da je Komisija kroz njih posredno odredila sadržaj ugovora o franšizingu i diktirala kretanje poslovne prakse.

Unatoč pozitivnom stavu prema prijenosu prava intelektualnog vlasništva putem ugovora o franšizingu, vodilo se računa i o tomu da se ne zlorabe pogodnosti skupog izuzeća. Posljednjim uvjetom ostavljena je mogućnost proglašenja nekoga vertikalnog ograničenja nedopustivim ako ima za cilj ostvarenje teških ograničenja tržišnog natjecanja ili ograničenja koja nisu obuhvaćena područjem primjene Uredbe 330/2010. U tom slučaju ugovorne odredbe koje sadrže takva vertikalna ograničenja bile bi ex lege ništetne.

\subsubsection{Ugovorne odredbe o zaštiti know-howa}

Od svih oblika prava intelektualnog vlasništva, ugovorom o franšizingu najčešće se prenosi know-how. Stoga se na ovom mjestu raspravlja o pitanjima opsega i svrhe u kontekstu europskog prava tržišnog natjecanja. Opseg zaštite know-howa nije apsolutan, već počiva na presumpciji da što je važniji njegov prijenos, vjerojatnije je da je zaštita neophodna i da će vertikalna ograničenja nametnuta primatelju franšize proizvoditi pozitivne učinke na tržišstu ${ }^{57}$.

Osim uvjeta spomenutih kod svih prava intelektualnog vlasništva, knowhow mora ispunjavati još i dodatne uvjete za ocjenu dopuštenosti takvih zaštitnih vertikalnih ograničenja. Dodatni uvjeti propisuju da know-how ne smije biti opće poznat ili lako dostupan. On mora obuhvaćati informacije koje su bitne i korisne za primatelja franšize i mora biti opisan na razumljiv način kako bi bilo moguće provjeriti ispunjava li kriterije tajnosti i značajnosti. Sav preneseni know-how mora biti neophodan za funkcioniranje poslovanja, što se prosuđuje iz perspektive primatelja franšize. Za odobrenje vertikalnih ograničenja zahtijeva se još i da je davatelj franšize osobno ili putem svojih zastupnika (trgovinskih zastupnika, posrednika, konzultanata

57 Smjernice o vertikalnim ograničenjima $\S 90$ (a). 
i istraživača tržišta koji rade za davatelja franšize) pružio poduke o korištenju knowhowa ${ }^{58}$ Davatelj franšize ima pravo za vrijeme trajanja ugovora zahtijevati od primatelja franšize da koristi know-how samo na ugovoreni način. To predstavlja obvezu primatelja franšize da know-how, koji mu je prenio, davatelj franšize ne koristi u druge svrhe ${ }^{59}$. Prenesene upute o korištenju ne moraju nužno biti u pisanom obliku, dovoljno je postojanje programa, audio, video ili audio-video snimaka koji sadrže upute koje primatelj franšize može koristiti na svome računalu. ${ }^{60}$

Iako to izrijekom nije navedeno u Uredbi 330/2010, ovisno o razdoblju na koje se odnose vertikalna ograničenja, odredbe o zaštiti know-howu mogu se podijeliti na one koje se ugovaraju prije, tijekom i nakon prestanka ugovora o franšizingu. Ova je podjela nužna i prihvatljiva sa stajališta nametanja vertikalnih ograničenja $\mathrm{s}$ obzirom na to da je ugovor o franšizingu dugotrajan i rizičan proces, pa se stoga u svakom od spomenutih razdoblja zahtijeva stroga povjerljivost i čuvanje knowhowa primatelja franšize ${ }^{61} \mathrm{~S}$ obzirom na to da je u pogledu nametanja vertikalnih ograničenja za zaštitu know-howa najviše otvorenih pitanja vezano uz razdoblje prije i poslije sklapanja ugovora o franšizingu, na ovom mjestu dodatno se analiziraju ta razdoblja. Navedena analiza nužna je jer se u Uredbi 330/2010 vodilo računa samo o vertikalnim ograničenjima radi očuvanja know-howa tijekom i nakon prestanka ugovora o franšizingu, bez regulacije razdoblja prije sklapanja ugovora.

Posebnost ugovora o franšizingu je ta što već tijekom pregovora davatelj franšize mora otkriti velik dio know-howa kako bi primatelj franšize znao što se od njega očekuje i je li spreman za takav poslovni rizik. ${ }^{62}$ Stoga primatelj franšize mora moći koristiti se pogodnostima pravila tržišnog natjecanja i nametnuti vertikalna ograničenja, tj. obvezu čuvanja know-howa i tijekom pregovora (engl. franchise disclosure document, skr. FDD). Kako Uredba 330/2010 izrijekom ne propisuje (niti zabranjuje) mogućnost zaštite know-howa u predugovornoj fazi, potrebno je posegnuti za drugim relevantnim pravnim vrelima koja se bave tom materijom $i$ ispitati njihov odnos i moguće implikacije na pravila tržišnog natjecanja.

Sustavna analiza dopuštenih vertikalnih ograničenja koja se tiču know-howa u razdoblju prije sklapanju ugovora o franšizingu nije moguća bez osvrta na djelovanje Međunarodnog instituta za unifikaciju privatnog prava (dalje: UNIDROIT). ${ }^{63}$ Jedan

58 Ibid.

59 Smjernice o vertikalnim ograničenjima $\S 45$.

60 Ibid. § 45. d.

61 Odluka Computerland $\S 5$ i $§ 22$ (i).

62 O predugovornoj odgovornosti u državama članicama EU-a vidi u: Abell, M., The Regulation of Franchising in EU Member State, International Journal of Franchising Law, Clarehout, London, 2012., vol. 10., br. 2., str. 18. Detaljnije o predugovornoj odgovornosti u Njemačkoj u pogledu ugovora o franšizingu vidi u: Dunisch, R., Legal Situation of Franchising in Germany, Oklahoma City University Law Review, vol. 24., br. 1. i 2., Oklahoma, str. 110.

63 Engl. The International Institute for the Unification of Private Law. UNIDROIT međunarodna je organizacija utemeljena 1926. godine sa sjedištem u Rimu. Danas broji 61 državu članicu. Do sada je priredio preko 70 studija i nacrta pravnih akata, od kojih su mnogi usvojeni kao međunarodne konvencije ili model-zakoni na diplomatskim konferencijama u organizaciji UNIDROIT. Više o radu UNIDROIT vidi: http://www.unidroit. org/english/presentation/ achievements.htm (23.3.2016.). 
od najvažnijih dokumenata koje je donio UNIDROIT jest Model zakon o otkrivanju podataka u franšizingu (dalje: Model zakon) ${ }^{64}$ Riječ je o savjetodavnom izvoru prava (tzv. soft law) nastalom komparativnom analizom međunarodnih pravnih sustava koji, između ostalog, regulira obvezu istinitog i potpunog otkrivanja know-howa davatelja franšize u fazi pregovora pri sklapanju ugovora o franšizingu. Slijedom navedenog, postavlja se pitanje odnosa Model zakona i pravila o zaštiti tržišnog natjecanja EU-a. U odnosu na kogentna pravila europskoga prava tržišnog natjecanja može se ustvrditi da se Model zakon ne primjenjuje na ugovor o franšizingu ako nije izrijekom ugovorena njegova primjena, već ima samo savjetodavnu ulogu. S druge strane, pravila tržišnog natjecanja kogentne su naravi i primjenjuju se uvijek bez potrebe da se na njih pozove i bez mogućnosti isključenja njihove primjene. Proizlazi da bi se unatoč visokoj usklađenosti ovih pravila, u slučaju njihova neslaganja primjenjivala pravila tržišnog natjecanja EU-a ispred Model zakona. ${ }^{65}$

Osim ovog načelnog odnosa, može se utvrditi da se Model zakon i pravila tržišnog natjecanja međusobno nadopunjuju u pogledu problematike know-howa kod ugovora o franšizingu. Naime, Model zakonom posredno su obuhvaćena pitanja koja se odnose i na pravila europskoga prava tržišnog natjecanja. Naime, u Model zakonu navodi se da je davatelj franšize jača pregovaračka strana koja će ako dođe do sklapanja ugovora moći nametnuti vertikalna ograničenja koja u drugim ugovorima ne bi mogao nametnuti. Stoga se inzistira na otkrivanju točnih, potpunih $i$ istinitih podataka o know-howu primatelju franšize već u fazi pregovora. ${ }^{66}$ Ako bi takvi postupci davatelja franšize u predugovornoj fazi zaista ostvarili negativan utjecaj na tržišno natjecanje tijekom trajanja ili nakon prestanka ugovora, primatelj franšize bi se mogao pozivati na utvrđenje ništetnosti spornih ugovornih odredbi i prema pravilima tržišnog natjecanja. Upravo je u takvim situacijama vidljiv odnos pravila tržišnog natjecanja EU-a i Model zakona. Slijedom navedenoga, može se zaključiti da iako se Model zakon bavi pitanjima otkrivanja podataka koja se tiču know-howa u fazi prije sklapanja ugovora, a pravila tržišnog natjecanja reguliraju tu materiju s naglaskom na razdoblje za vrijeme i nakon prestanka ugovora o franšizingu, rezultat njihova uređenja u konačnici je isti.

Uvjerljivo najviše spornih pitanja sa stajališta tržišnog natjecanja povlači obveza čuvanja know-howa i zabrana natjecanja primatelja $\mathrm{s}$ davateljem franšize nakon prestanka ugovora o franšizingu. Obveza čuvanja poslovnih tajni sukladno postojećim pravilima EU-a može se i trajno ugovoriti, tj. sve dok preneseni know-

64 Engl. Model Franchise Disclosure Law.

65 Model zakon u potpunosti je harmoniziran s pravilima europskog prava tržišnog natjecanja pa su stoga u praksi takve diskrepancije gotovo nemoguće. Može se utvrditi da je opravdano upotrijebiti UNIDROIT pravila kao dopunski izvor prava, budući da su nastala uzimajući u obzir pravo EU-a.

66 U čl. 121. Model zakon nalaže da davatelj franšize mora u postupku pregovora obavijestiti o svim obvezama koje od njega očekuje prije i poslije sklapanja ugovora o franšizingu (npr. odredbe o nenatjecanju). Osobito važno sa stajališta pravila tržišnog natjecanja je to što Model zakon zahtijeva otkrivanje know-howa samo davatelja franšize. Smatra se da se davatelju franšize ne treba pružiti isti stupanj zaštite kao i primatelju franšize. Proizlazi da je tim više mudro ugovoriti primjenu Model zakona na ugovor o franšizingu. Tekst Model zakona dostupan je na engleskom jeziku: http://www.unidroit.org/instruments/franchising/model-law, (30.6.2016.). 
how ne postane javan. U odnosu na ovaj uvjet potrebno je ukazati na sporna pitanja. Nejasno je kako bi takva zabrana egzistirala ako se primatelj franšize, nakon prestanka ugovora o franšizingu, počne baviti istim predmetom poslovanja koristeći know-how koji je stekao za vrijeme trajanja ugovora o franšizingu. U tom bi slučaju trebalo primijeniti pretpostavku važnosti (iz perspektive primatelja franšize) prenesenog know-howa. To se prema postojećoj regulativi radi na način da se procjeni u kojoj je mjeri preneseni know-how bio nov primatelju franšize u trenutku sklapanja ugovora o franšizingu i koliko je bio važan primatelju franšize za vođenje franšiznog poslovanja. Kako je ocjena važnosti prepuštena diskrecijskoj ocjeni primatelja franšize, a ne objektivnim parametrima moguće je očekivati da će jedan primatelj franšize ocijeniti franšizni know-how kao ne važan, dok će drugi primatelj franšize za isti takav knowhow smatrati da je važan. Stoga je potrebno izmijeniti postojeće uređenje na način da će se pri ocjeni važnosti u obzir uzimati i drugi objektivni kriteriji prema kojima bi se vršila ova ocjena (npr. ocjena davatelja franšize, ispitivanje tržišta, relevantnih stručnjaka, radnika i dr.).

Nije razjašnjena niti situacija kako bi se tretirala obveza povjerljivosti nakon prestanka ugovora o franšizingu, ako know-how postane dostupan javnosti tijekom trajanja ugovora ${ }^{67}$ Može se zaključiti da bi takva odredba bila ništetna sa stajališta europskoga prava tržišnog natjecanja jer bi bila riječ o nedostatku odlučne činjenice tajnosti za proglašenje njezine dopustivosti sukladno Uredbi 330/2010.

Takvo uređenje zaslužuje kritiku jer u praksi može izazvati puno spornih situacija. Primjerice, postavlja se pitanje kako će se prosuditi situacija u kojoj je know-how posao javan jer ga je primatelj franšize otkrio trećim osobama, a davatelj franšize to ne može dokazati? U tom slučaju u odnosu na treće, davatelj franšize nema pravo zahtijevati zabranu natjecanja, dok s druge strane ne može spriječiti primatelja franšize u natjecanju na tržištu jer je predmetni know-howa postao javan i kao takav više ne uživa pravo na zaštitu. Tu bi stoga bilo praktičnije izmijeniti tekst Uredbe 330/2010 i ograničiti rok zabrane na jednu godinu nakon prestanka ugovora o franšizingu (kao i u pogledu zabrane natjecanja) bez obzira je li u tom roku preneseni know-how postao javan ili nije. ${ }^{68}$

Nužno je ukazati i na određene proturječnosti u nametanju vertikalnih ograničenja vraćanju novonastalog know-howa i ostalih oblika prava intelektualnog vlasništva koja nastanu u radu ili u vezi s radom u franšiznoj mreži. S jedne strane, u Smjernicama o vertikalnim ograničenjima ${ }^{69}$ propisana je obveza primatelja franšize da na davatelja franšize nakon prestanka ugovora o franšizingu prenese sav know-how

67 Vidi: Smjernice o vertikalnim ograničenjima § 43. i EU Distribution Law, str. 156.

68 Od zabrana natjecanja dopušteno je samo ugovoriti da se primatelj franšize za vrijeme trajanja ugovora ili u razumno vrijeme nakon prestanka ugovora, suzdrži od izravnog ili neizravnog, osobnog ili putem drugih bavljenja sličnim poslom koji su predmet franšizinga. $U$ to spada obveza korisnika franšize da ne sudjeluje u temeljnom kapitalu poduzetnika, koji su natjecatelji davatelja franšize, koje bi mu omogućilo da utječe na poslovno ponašanje tog poduzetnika, zatim zabrana da se u razumnom roku nakon prestanka ugovora otvori ista ili slična vrsta prodavaonice u području na kojem bi moglo doći do natjecanja s drugim primateljima franšize. Vidi Smjernice o vertikalnim ograničenjima § 31-45. i predmet Pronuptia § 16.

69 Smjernice o vertikalnim ograničenjima $\S 45 \mathrm{~d}$. 
stečen za vrijeme korištenja franšize, kao i da davatelju franšize i drugim korisnicima franšize dodijeli neisključivu licencu za korištenje know-howa stečenog na temelju tih iskustava. S druge strane, takva analogna obveza povrata nije izrijekom predviđena za druge novonastale oblike intelektualnog vlasništva koje je primatelj franšize stvorio ili zaštitio pri ovlaštenim uredima za zaštitu intelektualnog vlasništva tijekom trajanja ugovora o franšizingu.

Spomenuta pitanja relevantna su sa stajališta europskoga prava tržišnog natjecanja jer su ugovori o franšizingu primjer gdje se znanja i iskustvo prosljeđuju primatelju franšize kako bi potonji ojačao svoj položaj na tržištu. Ipak, takav prijenos predstavlja rizik za davatelja franšize pa mu se omogućuje ugovaranje vertikalnih ograničenja kojima će moći zahtijevati vraćanje, ne samo prenesenog, nego i novonastalog know-how. ${ }^{70}$ Kako se obveza povrata novonastalih prava intelektualnog vlasništva nakon prestanka ugovora o franšizingu sukladno postojećoj regulativi EU-a odnosi samo na know-how, a ne i na druga prava intelektualnog vlasništva, u potonjim slučajevima postoji mogućnost negativnog utjecaja na tržišno natjecanje.

Manjkavost trenutnog uređenja i utjecaj na tržišno natjecanje najbolje se može demonstrirati na sljedećem primjeru. Uzmimo da je radnik primatelja franšize za vrijeme korištenja stroja za pravljenje brze hrane dobio ideju kako stvoriti novi stroj koji bi unaprijedio franšizno poslovanje i o tomu obavijestio svoga poslodavca (primatelja franšize). Kako je u većini europskih zakonodavstava propisano da poslodavcu pripadaju novonastali izumi radnika stvoreni na radu ili u vezi s radom, proizlazi da bi takav novi stroj, ako se zaštiti kao patent pripadao primatelju franšize. ${ }^{71}$ Tu davatelj franšize ne bi imao nikakvih prava ako izrijekom ne proširi obvezu povrata i drugih novonastalih oblika intelektualnog vlasništva nakon prestanka ugovora. S druge strane, ako bi radnik za vrijeme rada na stroju za pečenje došao do novog knowhowa za korištenje stroja, tako stečeni know-how pripadao bi davatelju franšize. ${ }^{72}$ Ako primatelj franšize propusti izrijekom ugovoriti obvezu da svi oblici intelektualnog vlasništva nakon prestanka ugovora o franšizingu pripadaju njemu, proizlazi da bi izum pripadao primatelju franšize i da bi on mogao pokrenuti postupak zaštite svoga izuma kao patenta. ${ }^{73}$ Osim toga, primatelj franšize kao vlasnik novonastalog patenta,

70 Tako stajalište zauzeto je i u Smjernicama o vertikalnim ograničenjima § 43-45.

71 Isto rješenje propisuje i hrvatski Zakon o radu, NN br. 93/14 (dalje: Zakon o radu) u čl. 98 kojim je propisano da izum radnika stvoren na radu ili u vezi s radom pripada poslodavcu. Pod izum stvoren u vezi s radom potpadali bi tako slučajevi u kojima izum ima izravne veze s poslovima i radnim zadatcima koje obavlja radnik tijekom radnog vremena, ali je izum rezultat radnikovih radnih i istraživačkih napora u slobodnom vremenu. Detaljnije o uređenju intelektualnog vlasništva nastalog u radnom odnosu u komparativnim zakonodavstvima vidi u: Matanovac Vučković, R., Kunda I., Materijalnopravno i kolizijskopravno uređenje intelektualnog vlasništva nastalog u radnom odnosu, Zbornik Pravnog fakulteta Sveučilišta u Rijeci, 2011., v. 32., br. 1, str. 75-125. Usporedi: Ruždjak, M., Šribar P., Zuber, M., Zakon o radu s komentarom, Inženjerski biro, Zagreb, 1995., str. 88.

72 Iako je u praksi gotovo nemoguće zamisliti da bi, primjerice, izum koji bi stvorio primatelj franšize tijekom trajanja ugovora o franšizingu prošao postupak registracije i postao zaštićen kao vlasništvo primatelja franšize. Ako se to ipak dogodi, primatelju franšize ne bi pripadao patent, čak i da se on izravno tiče franšize ili je nastao u vezi s radom u franšiznoj mreži.

73 Ova problematika može se dodatno zakomplicirati u onim zakonodavstvima u kojima se pod 
mogao bi pokrenuti vlastitu franšiznu mrežu koja bi se bavila istim predmetom poslovanja u drugom poslovnom prostoru i u njoj upotrebljavati napredniji stroj bez bojazni da će se davatelj franšize moći pozivati na kršenje pravila tržišnog natjecanja.

Slijedom navedenoga, u budućim aktima kojima se uređuju skupna izuzeća, potrebno je proširiti obvezu vraćanja na sve novonastale oblike intelektualnog vlasništva. Do tada bi sa stajališta zaštite tržišnog natjecanja bilo oportuno prevenirati ovaj propust Komisije i ugovorom proširiti obvezu povrata svih novonastalih oblika intelektualnog vlasništva nakon prestanka ugovora o franšizingu koje je primatelj franšize stvorio za vrijeme trajanja ugovora o franšizingu ili u vezi s obavljanjem poslova franšize. Takva ugovorna odredba ne bi predstavljala povredu tržišnog natjecanja, a s druge strane, išla bi u korist davatelju franšize i doprinosila bi zaštiti tržišnog natjecanja. ${ }^{74}$

određenim pretpostavkama odnos davatelja i primatelja franšize može smatrati radnim odnosom. Takav bi patentirani stroj pripadao davatelju franšize jer bi se primjenom pravila radnog prava smatralo da patenti stvoreni na radu i u vezi s radom pripadaju poslodavcu, odnosno u ovom slučaju davatelju franšize. S druge strane, poimanjem ugovora o franšizingu kao ugovora o radu ne bi više postojali uvjeti za primjenu vertikalnih ograničenja europskih pravila tržišnoga natjecanja. U njemačkoj i austrijskoj sudskoj praski pojavilo se pitanje može li se i pod kojim uvjetima primatelj franšize smatrati radnikom davatelja franšize. Njemački su sudovi odredili kriterije prema kojima se ova naizgled nelogična poveznica može prihvatiti i primijeniti na ugovor o franšizingu. To će biti ako primatelj franšize nije ovlašten samostalno poduzimati nikakve materijalne poslovne odluke, tj. kada je u potpunosti ekonomski ovisan o davatelju franšize. Primjeri su takvih odredbi nemogućnost primatelja franšize da sam organizira svoje radno vrijeme i godišnji odmor, mjesto, trajanje i način rada, ako se na tržištu ne može pojaviti kao samostalni poduzetnik koji radi za svoj račun, u svoje ime i na svoju vlastitu odgovornost, ako nema mogućnost ostvarivanja prihoda od drugih kompanija ili sporednih linija, ako nema gotovo nikakvu slobodu odlučivanja i sl. Sličan stav zabilježen je i u austrijskoj sudskoj praksi gdje prevladava mišljenje da primatelj franšize treba biti potpuno neovisan poduzetnik koji djeluje u svoje ime i za svoj račun. Navedeni primjeri odredbi nisu ultimativni znak da je riječ o ravnopravnom odnosu između davatelja i primatelja franšize već se procjena stupnja slobode i vrste ugovora treba procjenjivati od slučaja do slučaja. Ako se utvrdi da je riječ o ravnopravnom odnosu tada primatelj franšize treba uživati istu pravnu zaštitu koju uživa radnik u odnosu na svog poslodavca. Usporedi: presuda Saveznog vrhovnog radnog suda Njemačke (njem. Bundesarbeitsgericht BAG), broj NZA 1997. od 16.7.1997., str. 1126., presuda njemačkoga regionalnog radnog suda u Düsseldorfu (njem. Landesarbeitgericht Düsseldorfu), broj NJW 1988 od 20.10.1987, § 72., presuda Vrhovnog suda Austrije: (njem. Oberster Gerichtshofund Generalprokuratur OGH), br. 4, Ob 321/87 od 05.05.1987. Dostupno na njemačkom jeziku na: https://www.ris.bka.gv.at/Dokument.wxe?A bfrage=Justiz\&Dokumentnummer=J JT_19870505_OGH0002_0040OB00321_8700000_000 (21.3.2016.). O sudskoj praksi u Austriji u kontekstu spomenute analogije detaljnije vidi: Spiegelfeld, B., Krenn, M., Austria- Recent Decisionsof the Supreme Court related to distribution relationships, International Journal of Franchising Law, vol. 8., br. 1., Clarehout, London, 2010., str. 5-7.

74 U prilog tezi da se zaštita ostalih oblika intelektualnog vlasništva u potpunosti previdjela ide i odluka Komisije Yves Rocher. U njoj je izrijekom naglašeno da odredba o vraćanju stečenog i novonastalog know-howa ne sprječava primatelja franšize da se nakon prestanka ugovora o franšizingu bavi istim predmetom poslovanja. Smisao odredbe jest da se primatelj franšize obveže da neće obavljati i poduzimati radnje unutar istog predmeta poslovanja u kojem bi koristio preneseni ili novonastali know-how ili ga otkrivao trećim osobama, jer to predstavlja nepravednu dobit za primatelja franšize i natjecatelje na tržištu. Stoga se u konkretnom slučaju 


\subsubsection{Ugovorne odredbe nužne za očuvanje identiteta i ugleda franšizne mreže}

Radi očuvanja identiteta i ugleda franšizne mreže dopušteno je nametanje pravila poslovanja i usklađenog djelovanja u cijeloj franšiznoj mreži davatelja franšize jer ona doprinose jedinstvenosti franšizne mreže i standardizaciji kvalitete. Primjeri takvih dopuštenih ugovornih odredbi vertikalna su ograničenja koja se tiču davanja preporučene i/ili maksimalne cijene (ali ne i fiksnih i/ili minimalnih cijena), odredbe o zabrani natjecanja za vrijeme trajanja ugovora i razumno vrijeme nakon prestanka ugovora o franšizingu, zatim odredbe o izboru, izgledu i načinu korištenja poslovnih prostora, nabavljanju robe i održavanju robnih zaliha, kontroli poslovanja i dr. Neke od ovih ugovornih odredbi potrebno je dodatno razjasniti.

U pogledu poslovnih prostora davatelj franšize može u određenim slučajevima nametnuti vertikalna ograničenja oko izbora lokacije, izgleda i dekoracije cijelog ili dijela poslovnog prostora i sl. ${ }^{75} \mathrm{Tu}$ spada i obveza primatelja franšize da ne koristi franšizne robne marke, tvrtku i druge identifikacijske oznake bilo gdje osim na ugovorenoj franšiznoj lokaciji kao i da ih prestane koristiti nakon prestanka ugovora ${ }^{76}$, zabrana obavljanja radnji u poslovnom prostoru koje su nespojive $s$ franšizom ${ }^{77}$, tj. koje su izvan predmeta poslovanja franšize.$^{78} \mathrm{Kod}$ ovih vertikalnih ograničenja polazi se od pretpostavke da je davatelj franšize pomagatelj primatelja franšize. ${ }^{79}$ Suradnja je u njihovu zajedničkom interesu jer loš izbor lokacije može uzrokovati pad poslovanja ili posredno nanijeti štetu ugledu franšizne mreže.

Za bolje razumijevanje svrhe ovih odredbi može poslužiti primjer iz odluke Yves Rocher gdje se provodilo ispitivanje potencijalnih tržišta i lokacijske ankete, nakon čega su primatelju franšize predložene najbolje lokacije dobivene na temelju provedenih istraživanja i anketa. Na kraju je točnu lokaciju poslovnog prostora utvrdio primatelj franšize u dogovoru s davateljem franšize, tj. u zajedničkom interesu svih članova franšizne mreže ${ }^{80}$

Drugu važnu skupinu dopuštenih vertikalnih ograničenja predstavljaju odredbe koje se tiču robe koja je predmet ugovora o franšizingu (engl. tying arrangement, tie-

ugovaranje zabrane natjecanja u smislu zabrane korištenja i prenošenja know-howa smatra dopuštenim jer je to jedina učinkovita metoda sprječavanja otkrivanja know-howa. Vidi odluka Yves Rocher $\S 47$. do 49.

75 Predmet Pronuptia § 19, odluka Computerland $§ 23$ (v); odluka Yves Rocher $\S 43$.

76 Odluka Computerland $\$ 23$ (ii).

77 Odluka Yves Rocher § 49; odluka Computerland § 23 (iv); predmet Pronuptia § 19.

78 Odluka Computerland § 23 (iv).

79 S druge strane takve odredbe ne bi bile dopuštene u sustavu selektivne distribucije gdje dobavljač djeluje samo u svom vlastitom interesu. Vidi Computerland § 23. i EU Distribution Law, str. 159.

80 Vidi u odluci Yves Rocher § 46. U odluci Computerland naglašeno je da se izbor lokacije treba temeljiti na objektivnim kriterijima kako bi se osigurao uspjeh poslovnice i kako se ne bi naštetilo poslovanju zbog lošeg izbora lokacije. Dakle, ova obveza je dopuštena samo ako postoje objektivni kriteriji koji dokazuju da bi se određena lokacija mogla negativno odraziti na ugled franšizne mreže. Dopušteno je nametnuti čak i obvezu korištenja franšize samo na određenim lokacijama i zabraniti njezino mijenjanje bez pristanka davatelja franšize. Vidi: odluka Computerland $§ 23$ (v); odluka Yves Rocher § 42; predmet Pronuptia § 19. 
in clause $\left.^{81}\right)$. Primjerice, to je obveza primatelja franšize da ne prodaje natjecateljske proizvode $^{82}$, obveza održavanja robnih zaliha i naručivanja robe od davatelja franšize prema unaprijed određenom rasporedu ${ }^{83}$ zatim ugovaranje kontrole kvalitete robe nabavljene od drugih dobavljača, zabrana prodaje bilo koje druge robe osim one koju je odobrio davatelj franšize ili kojom je opskrbio primatelja franšize pod uvjetom da je takva zabrana nužna kako bi se očuvao zajednički identitet i ugled franšizne mreže. ${ }^{84}$ Tu bi pripadala i obveza prodaje robe koja nosi robni žig samo krajnjim korisnicima, a ne i drugim dobavljačima koji nisu članovi franšizne mreže (engl. selective dealing). ${ }^{85}$

Procjena valjanosti vrši se od slučaja do slučaja. Takve odredbe nikada se ne mogu ugovoriti kako bi se spriječilo primatelja franšize da nabavi robu od drugih primatelja unutar franšizne mreže. Bitno je za naglasiti da postoji razlika u dopuštenosti ovakvih zabrana $\mathrm{u}$ franšiznim sustavima $\mathrm{u}$ kojima se franšiza zasniva na prodaji proizvoda putem točno određenog robnog žiga i simbola koji se nalazi na svakom proizvodu (poput onog u predmetu Yves Rocher) ${ }^{86}$ i franšiznog sustava u kojem proizvodi ne nose poseban znak ili oznaku koja ih povezuje s franšiznom mrežom (poput onog u predmetu Computerland). ${ }^{87}$ Može se očekivati da će strože kontrole biti kada proizvodi obvezno nose robni žig. Važno je napomenuti da primatelju franšize i u

81 Lovrić, A., Licencni ugovor o prijenosu prava intelektualnog vlasništva s posebnim osvrtom na restriktivne klauzule u tom ugovoru, magistarski rad, Pravni fakultet Sveučilišta u Zagrebu, Osijek, 1988., str. 32.

82 Predmet Pronuptia $\S 21$. Ova se ugovorna odredba tretira puno strože kod drugih ugovora za razliku od ugovora o franšizingu.

83 Ibid. Davatelj franšize može u određenim uvjetima zabraniti primatelju franšize prodaju sve robe osim one koju mu je on dostavio ili ako ju je odobrio davatelj franšize. Vidi odluku Yves Rocher $\S 45$ i $\S 50$.

84 Predmet Pronuptia $§ 17$.

85 Detaljnije o selektivnoj distribuciji unutar EU-a vidi: Vajda, C., Selective Distribution in the European Community, Journal of World Trade Law, vol. 13, br. 5 (1979), str. 409-435. Ova odredba nalaže prodaju samo potrošačima kao krajnjim kupcima i/ili drugim primateljima franšize. Samo kod određenih vrsta franšize ovakva odredba nije povreda čl. 101. st. 1. UFEU-a. To je izrijekom navedeno i u odluci Computerland gdje je naglašeno da će drugi preprodavači koji nisu članovi franšizne mreže, tj. nemaju pristup know-howu i nisu ograničeni obvezama nametnutim radi očuvanja identiteta i ugleda franšizne mreže i njezinih identifikacijskih oznaka moći koristiti prednosti koje im ne pripadaju. Vidi odluku Computerland § 25.

86 Komisija je u odluci Yves Rocher postavila pravilo u kojem je moguće nametnuti obvezu prodaje točno određene robe u slučaju da se u poslovnim prostorima prodaje samo roba koja nosi robni žig davatelja franšize. U tom bi slučaju prodaja tuđe robe omogućila drugim proizvođačima da steknu nezasluženu prednost zahvaljujući ugledu i know-how davatelja franšize što bi negativno utjecalo na identitet franšizne mreže. S druge strane, nabavljanje inventara i drugih dodataka mogu se u tom slučaju nabavljati i od drugih izvora. Vidi: odluka Yves Rocher § 45.

87 Komisija je u odluci Computerland zaključila da je davatelj franšize imao pravo davati prethodno odobrenje u slučaju kupnje računalne opreme od drugih dobavljača. U tom predmetu bila je riječ o području gdje se tehnologija brzo razvija, pa bi opća zabrana bila suprotna zabrani da primatelj franšize prodaje najsuvremenije proizvode. Ipak, potreba očuvanja franšizne mreže bila je zadovoljena na temelju obveze ishođenja prethodnog odobrenja za kupnju takve robe davatelja franšize. Takva je obveza prihvaćena jer su davatelji franšize u praksi imali razmjeran utjecaj na predlaganje proizvoda koji podliježu prethodnom odobrenju. Vidi: odluka Computerland $\S 25$ (vi). 
tom slučaju mora biti omogućeno nabavljati proizvode i robu koja nije povezana s bitnim predmetom franšize od bilo kojeg dobavljača po njegovu izboru (npr. sredstva za čišćenje poslovnog prostora). Ipak, i tada davatelj franšize može i dalje kontrolirati kvalitetu takve robe i može intervenirati ako bi ona mogla štetno utjecati na ugled franšizne mreže ${ }^{88}$

Zadnje dvije vrste vertikalnih ograničenja koje je potrebno posebno istaknuti su zabrana oglašavanja bez odobrenja davatelja franšize i kontrola poslovanja. Zabrana oglašavanja je dopuštena samo ako se takvim ograničenjem ne nameću fiksne i minimalne cijene ili dodatna ograničenja. ${ }^{89}$ Dopuštena kontrola poslovanja, odnosi se primjerice, na provjeru robnih zaliha, računa i bilance davatelja franšize.$^{90} \mathrm{Tu}$ spada $\mathrm{i}$ obveza primatelja franšize da redovito predaje točna i istinita izvješća i račune..$^{91}$

\subsection{Zabranjene ugovorne odredbe}

Kod ugovora o franšizingu puno je manji broj izrijekom zabranjenih ugovornih odredbi u odnosu na druge vrste vertikalnih sporazuma. Većina se teških ograničenja tržišnog natjecanja (članak 4. Uredbe 330/2010) ili ograničenja koja se ne mogu izuzeti (članak 5. Uredbe 330/2010) derogiraju budući da se nastoji očuvati smisao sklapanja ugovora o franšizingu.

Neke od apsolutno zabranjenih ugovornih odredbi raspravljane su u praksi Europskog suda i Komisije. Navodi se da činjenica da davatelj franšize daje preporučene cijene primatelju franšize ne predstavlja ograničenje tržišnog natjecanja, sve dok nije riječ o usklađenom djelovanju između davatelja i primatelja franšize ili između primatelja franšize koji međusobno imaju za cilj stvarnu primjenu takvih cijena. ${ }^{92} \mathrm{~S}$ druge strane, izrijekom se spominje da je zabranjeno nametati fiksne ili minimalne cijene proizvoda i usluga (engl. resale price maintenance ${ }^{93}$ ), dogovarati podjele tržišta i ugovarati trajnu zabranu obavljanja iste djelatnosti nakon prestanka ugovora o franšizingu. Svaki takav pokušaj koji nametne davatelj franšize smatrat će se teškom povredom tržišnog natjecanja. ${ }^{94}$ U odluci Komisije u predmetu Pronuptia Komisija je zatražila od davatelja franšize Pronuptia da ukloni ugovornu odredbu koja je sadržavala obvezu primatelja franšize da ne povrijedi sliku branda u pogledu razine cijena. Takva ugovorna odredba vjerojatno je imala za cilj odrediti minimalnu cijenu. $^{95}$

Osim toga, ugovorne odredbe kojima se ugovaraju podjele tržišta između davatelja i primatelja franšize ili između primatelja franšize međusobno predstavljaju

88 Vidi predmet Pronuptia $\S 25$.

89 Odluka Pronuptia § 22; odluka Computerland § 23. (vi), EU Distribution Law, str. 161.

90 Komisija je u odluci Yves Rocher ograničila pravo davatelja franšize na takvu vrstu kontrole ako time nastoji fiksirati cijene. EU Distribution Law, str. 162., odluka Yves Rocher $§ 23$ (viii) i odluka Computerland $\S 50$.

91 Odluka Charles Jourdan $§ 27$.

92 Predmet Pronuptia toč. 4. sažetak presude.

93 O tome detaljnije: Butorac Malnar, V. i dr., Pravo tržišnog natjecanja, str. 172.

94 Vidi odluka Yves Rocher $\S 51$ i odluka Charles Jourdan § 18. i § 29.

95 Odluka Pronuptia ECJ § 12. (c). 
povredu tržišnog natjecanja u smislu članak 101. stavak 1. UFEU-a. ${ }^{96} \mathrm{U}$ ugovorima o franšizingu koji, radi distribucije robe, sadrže ugovorne odredbe o podjeli tržišta između davatelja i primatelja franšize, ili između primatelja franšize međusobno, takve odredbe mogu utjecati na trgovinu između država članica, čak i ako su ugovorene između poduzetnika koji su osnovani u istoj državi članici, u mjeri u kojoj sprječavaju primatelje franšize da djeluju na tržištu u drugoj državi članici. ${ }^{97} \mathrm{U}$ navedeno pripada i zabrana otvaranja druge poslovnice koja je kombinirana s isključivosti teritorija jer predstavlja povredu članka 101. stavka 1 . UFEU-a pa dovodi do podjela tržišta. ${ }^{98}$

Zaključno, može se reći da je EU ispravno zauzeo pozitivan stav prema ugovoru o franšizingu i dao zeleno svjetlo za normalno funkcioniranje franšizne mreže. S druge strane, apsolutna zabrana nametanja fiksnih i minimalnih cijena, podjela tržišta i zabrana natjecanja u roku od maksimalno godinu dana od prestanka ugovora o franšizingu u dovoljnoj mjeri štite unutrašnje tržište EU-a i ne dopuštaju zloupotrebe.

\section{ZAKLJUČ AK}

Na prethodnim stranicama obrađena je problematika dopuštenih i zabranjenih ugovornih odredbi kod ugovora o franšizingu u kontekstu europskoga prava tržišnog natjecanja. Ovim radom nastojala se popuniti pravna praznina u hrvatskoj pravnoj literaturi koja je vrlo značajna, ne samo s teoretskog, nego i s praktičnog aspekta.

Sustavnom analizom ove materije uočeno je da je ugovaranje restriktivnih ugovornih odredbi dopušteno samo radi zaštite prava intelektualnog vlasništva davatelja franšize te očuvanja identiteta i ugleda franšizne mreže. Sve preko te granice zabranjeno je i smatra se da ima za cilj ili posljedicu sprječavanje, ograničavanje i narušavanje tržišnog natjecanja.

S obzirom na to da je nemoguće stvoriti univerzalne kriterije koji bi se jednako primjenjivali na sve ugovore o franšizingu, ocjena dopustivosti pojedinih ugovornih odredbi ili čak cijelog ugovora o franšizingu vrši se od slučaja do slučaja. U dvojbi je li neka ugovorna odredba dopuštena ili zabranjena sa stajališta europskoga prava tržišnog natjecanja mudrije je i praktičnije slijediti stavove Komisije. Naime, Komisija je autor najvećeg broja normativnih akata koji uređuje ovu materiju, a zbog dugotrajnosti i visine troškova postupka pred Sudom EU-a, ona je vrlo često i posljednja instanca EU-a koja prosuđuje o dopustivosti pojedinih ugovornih odredbi kod ugovora o franšizingu sa stajališta EU-a.

Osim toga, slijedeći trendove u komparativnoj sudskoj praksi poželjno je pri sklapanju ugovora o franšizingu dati primatelju franšize dovoljno ekonomskih i poduzetničkih sloboda kako bi mogao samostalno donositi svoje poduzetničke odluke.

Uzimajući u obzir navedene zaključke, može se reći da je pozitivan stav EU-a u odnosu na ugovor o franšizingu opravdan sa stajališta normalnog funkcioniranja franšizne mreže. S druge strane, uočen je i jedan negativan trend. Naime, nakon što je u posljednjim desetljećima postalo jasno da ugovaranje restriktivnih ugovornih

96 Vidi predmet Pronuptia toč. 3. sažetak presude.

97 Ibid., toč. 4. sažetak predmet Pronuptia.

98 EU Distribution Law, str. 152. 
odredbi ne predstavlja povredu europskoga prava tržišnog natjecanja, trebalo bi više pažnje obratiti na jačanje položaja primatelja u odnosu na davatelja franšize. Početni korak u rješavanju navedenoga problema bio bi određivanje jasnih kriterija kojima bi se prepoznale zloupotrebe davatelja franšize koje imaju za cilj nametanje prevelike kontrole i obveza primatelju franšize, odnosno povredu tržišnoga natjecanja unutar EU-a.

\section{LITERATURA}

1. Abell, M., The Regulation of Franchising in EU Member State, International Journal of Franchising Law, London, Clarehout, vol. 10, br. 2/2012.

2. Block, B., Ridings, M., D., Antitrust Conspiracies in Franchise System After American Needle, Franchise Law Journal, Chicago, vol. 30, 4/2011, str. 217-220.

3. Braun, W. D.; Ritter, L., EC Competition Law: a practicioner's guide, Den Haag, Kluwer Law International, 2000., III. izd., str. 263-380.

4. Butorac Malnar, V.; Pecotić Kaufman, J.; Petrović, S., Pravo tržišnog natjecanja, Zagreb, Pravni fakultet Sveučilišta, 2013.

5. Competition Policy and Vertical Restrains: Franchising Agreements, OECD, <http:// www.oecd.org/competition/abuse/1920326.pdf>, 22.3.2016.

6. Crafword Spencer, E., The Regulation of Franchising in the New Global Economy, Cheltenham, Edward Elgar Publishing Limited, 2010.

7. Dunisch, R., Legal Situation of Franchising in Germany, Oklahoma City University Law Review, vol. 24, br. 1. i 2.

8. Guide to International Master Franchise Arrangements, Rome, 2007., <http://www. unidroit.org/english/guides/2007franchising/franchising2007-guide-2nd-e.pdf $\geq$, 1.7.2016.

9. Hurley, E. R., Pronuptia de Paris vs. Schillgalis: Permissible Restrants of Trade on Franchising in the EEC, Northwestern Journal of International Law \& Business, Chicago, vol. 8., 2/1987, str. 476-477.

10. Goyder, J., EU Distribution Law, Oxford-Portland, Oregon, Hart Publishing, 2005.

11. Joseph, R. T., Antitrust Law, Franchising, and Vertical Restrains, Franchise Law Journal, Chicago, vol. 31., 1/2011.

12. Lovrić, A., Licencni ugovor o prijenosu prava intelektualnog vlasništva s posebnim osvrtom na restriktivne klauzule u tom ugovoru: magistarski rad, Osijek, Pravni fakultet Sveučilišta u Zagrebu, 1988.

13. Matanovac Vučković, R.; Kunda I., Materijalnopravno i kolizijskopravno uređenje intelektualnog vlasništva nastalog u radnom odnosu, Zbornik Pravnog fakulteta Sveučilišta u Rijeci, vol. 32., 1/2011, str. 75-125.

14. Mlikotin-Tomić, D., Ugovor o franchisingu i pravo konkurencije, Pravo u gospodarstvu, god. 39., 5/2000.

15. Mlikotin-Tomić, D., Ugovor o franchisingu, Zagreb, Informator, 1986.

16. Pošćić, A., Zabranjeni sporazumi u europskom pravu tržišnog natjecanja, Zbornik Pravnog fakulteta Sveučilišta u Rijeci, vol. 32., 1/2011, str. 322-328.

17. Ruždjak, M.; Šribar P., Zuber, M., Zakon o radu s komentarom, Zagreb, Inženjerski biro, 1995.

18. Spiegelfeld, B.; Krenn, M., Austria- Recent Decisionsof the Supreme Court related to distribution relationships, International Journal of Franchising Law, vol. 8., br. 1/2010.

19. Vajda, C. Selective Distribution in the European Community, Journal of World Trade Law, vol. 13, 5/1979, str. 409-435.

20. Zakon o radu, Narodne novine, br. 93/14. 
Summary

\section{PERMITTED AND PROHIBITED CONTRACTUAL PROVISIONS WITH FRANCHISE AGREEMENTS IN THE CONTEXT OF EUROPEAN COMPETITION LAW}

The relationship between a franchisor and franchisees with franchise agreements opens up a number of legal issues in European competition law, which so far have not been addressed in the domestic legal literature. On the one hand, the EU with franchise agreements allows the imposition of a large number of restrictive contractual provisions that would otherwise, in the normal course of things, have been forbidden. On the other hand, in practice, it is observed that the said restrictive limitations sometimes are used as a legitimate means to restrict competition and for weakening the position of franchisees. The goal of this work is, through the critical analysis of the relevant acquis communautaire of the EU, to provide a review of permitted and prohibited contractual provisions with franchise agreements in the context of European competition law and thus to answer the questions when and under what conditions specified protection becomes a platform for legitimate abuse.

In the first part, there are defined terms and acquis communautaire of the EU, concerning the subject matter. Then are analyzed permitted and prohibited contractual provisions between franchisees and franchisor with franchise agreements in the context of European competition law. In the end, there is a principled assessment of the situation and there is provided guidance for future developments of the EU regulatory activities and business practices with respect to this matter in the context of European competition law.

Keywords: Competition Law, vertical agreements, franchising agreement, vertical restraints, contractual provisions.

Zusammenfassung

\section{ERLAUBTE UND VERBOTENE VERTRAGLICHE BESTIMMUNGEN IN FRANCHISE-VEREINBARUNGEN IM RAHMEN DES EUROPÄISCHEN WETTBEWERBSRECHTS}

Die Beziehung zwischen dem Spender und Empfänger einer Franchise in Franchise-Vereinbarungen eröffnet eine Reihe von Rechtsfragen im europäischen Wettbewerbsrecht, die bisher nicht in der heimischen juristischen Literatur behandelt wurden. Auf der einen Seite ermöglicht die EU die Einführung einer großen Zahl von restriktiven Vertragsbestimmungen mit diesem Vertrag, die sonst verboten wären. Auf der anderen Seite kann in der Praxis beobachtet werden, dass 
die restriktiven Beschränkungen manchmal als legitime Mittel der Einschränkung des Marktwettbewerbs und Schwächung der Position der Franchise-Nehmer verwendet werden. Das Ziel dieses Artikels ist es, eine Überprüfung der zulässigen und verbotenen vertraglichen Regelungen in Franchise-Vereinbarungen anhand einer kritischen Analyse des relevanten acquis communautaire im Rahmen des europäischen Wettbewerbsrechts darzustellen, und damit die Fragen zu beantworten, wann und unter welchen Bedingungen wird der angegebene Schutz zu einer Plattform für legitimen Missbrauch.

Der erste Teil definiert die Begriffe und acquis communitaire im Kontext des analysierten Themas, danach werden die erlaubten und verbotenen Vertragsbestimmungen zwischen dem Empfänger und dem Franchise-Geber mit Franchise-Vereinbarungen im Rahmen des europäischen Wettbewerbsrechts analysiert. Am Ende wird eine prinzipielle Einschätzung der Situation und Hinweise für die künftige Entwicklung der EU-Regulierungstätigkeiten und Geschäftspraktiken in Bezug auf diese Angelegenheit im Rahmen des europäischen Wettbewerbsrechts gegeben.

Schlüsselwörter: Wettbewerbsrecht, vertikale Vereinbarungen, Franchisevereinbarungen, vertikale Beschränkungen, vertragliche Bestimmungen.

Riassunto

\section{AMMISSIBILITÀ ED INAMMISSIBILITÀ DELLE CLAUSOLE CONTRATTUALI NEL CONTRATTO DI FRANCHISING NELL'AMBITO DEL DIRITTO EUROPEO DELLA CONCORRENZA}

Il rapporto tra il l'affiliante e l'affiliato nel contratto di franchising apre numerose questioni giuridiche nel diritto europeo della concorrenza, le quali fino ad oggi non sono state oggetto di trattazione della letteratura giuridica interna. Da un lato, l'UE con riguardo a questo contratto permette l'imposizione di numerose disposizioni contrattuali restrittive, le quali in un normale corso delle cose sarebbero vietate. Dall'altra parte, nella prassi si nota che tali limitazioni restrittive talora vengano usate quale mezzo legittimo per la limitazione della concorrenza e per l'indebolimento della posizione dell'affiliato. Lo scopo del lavoro è di offrire in rassegna, mediante un'analisi critica dell'acquis dell'UE, quali siano le clausole contrattuali ammesse e quelle non ammesse nell'ambito del diritto europeo della concorrenza per rispondere così alle domande quando ed a che condizioni tale tutela divenga una piattaforma per un abuso legittimo.

Nella prima parte vengono definite le nozioni e l'acquis comunitario relativi alla materia in esame. In seguito si analizzano le clausole contrattuali ammesse e vietate tra l'affiliante e l'affiliato nel contratto di franchising nell'ambito del diritto europeo 
della concorrenza. Al termine si espongono le valutazioni di massima sullo stato delle cose e si danno delle indicazioni per futuri interventi normativi dell'UE, come pure della prassi d'affari in tale materia nell'ambito del diritto europeo della concorrenza.

Parole chiave: diritto della concorrenza, accordi verticali, contratto di franchising, limitazioni verticali, clausole contrattuali. 
